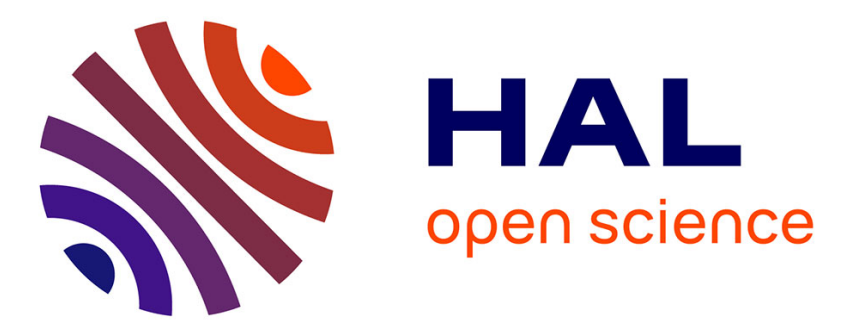

\title{
Change in geometry of a high Arctic glacier to 1948 to 2013 (Austre Lovénbreen, Svalbard)
}

Christelle Marlin, Florian Tolle, Madeleine Griselin, Eric Bernard, Albane Saintenoy, Mélanie Quenet, Jean Michel Friedt

\section{To cite this version:}

Christelle Marlin, Florian Tolle, Madeleine Griselin, Eric Bernard, Albane Saintenoy, et al.. Change in geometry of a high Arctic glacier to 1948 to 2013 (Austre Lovénbreen, Svalbard). Geografiska Annaler: Series A, Physical Geography, 2017, 99 (2), pp.115-138. 10.1080/04353676.2017.1285203 . hal-01470085

\section{HAL Id: hal-01470085 \\ https://hal.science/hal-01470085}

Submitted on 25 May 2021

HAL is a multi-disciplinary open access archive for the deposit and dissemination of scientific research documents, whether they are published or not. The documents may come from teaching and research institutions in France or abroad, or from public or private research centers.
L'archive ouverte pluridisciplinaire HAL, est destinée au dépôt et à la diffusion de documents scientifiques de niveau recherche, publiés ou non, émanant des établissements d'enseignement et de recherche français ou étrangers, des laboratoires publics ou privés. 


\title{
Change in geometry of a high Arctic glacier from 1948 to 2013 (Austre Lovénbreen, Svalbard)
}

\author{
Christelle Marlin $^{\mathrm{a}}$, Florian Tolle ${ }^{\mathrm{b}}$, Madeleine Griselin ${ }^{\mathrm{b}}$, Eric Bernard ${ }^{\mathrm{b}}$, Albane Saintenoy ${ }^{\mathrm{a}}$, \\ Mélanie Quenet ${ }^{\mathrm{a}}$ and Jean-Michel Friedt ${ }^{\mathrm{c}}$ \\ aLaboratoire GEOPS UMR 8148, Université Paris-Sud 11 - CNRS, Orsay Cedex, France; 'baboratoire ThéMA UMR 6049, \\ Université de Bourgogne Franche-Comté - CNRS, Besançon, France; ' Laboratoire FEMTO-ST UMR 6174, Université de \\ Bourgogne Franche-Comté - CNRS, Besançon, France
}

\begin{abstract}
The change of Austre Lovénbreen, a $4.5 \mathrm{~km}^{2}$ land-based glacier along the west coast of Spitsbergen, is investigated using geodetic methods and mass balance measurements over 1948-2013. For 2008 -2013 , annual mass balances computed on 36-stake measurements were obtained, in addition to annual mass balances reconstructed from the neighbouring glaciers, Midtre Lovénbreen (1968-2007) and Austre Brøggerbreen (1963-1967). The mean rate of glacier retreat for 1948-2013 is $-16.7 \pm 0.3 \mathrm{~m}$ $\mathrm{a}^{-1}$. Fluctuations in area (1948-2013 mean, $-0.027 \pm 0.002 \mathrm{~km}^{2} \mathrm{a}^{-1}$ ) showed a slowing as the glacier recedes within its valley from 1990 to 1995 . For 1962-2013, the average volume loss calculated by digital elevation model subtraction of $-0.441 \pm 0.062 \mathrm{~m}$ w.e. $\mathrm{a}^{-1}$ (or $-0.54 \pm 0.07 \% \mathrm{a}^{-1}$ ) is similar to the average annual mass balance $\left(-0.451 \pm 0.007 \mathrm{~m}\right.$ w.e. $\left.\mathrm{a}^{-1}\right)$, demonstrating a good agreement between the loss rates computed by both methods over 1962-2013. When divided in two periods (1962-1995 and 1995-2013), an increase in the rate of ice mass loss is statistically significant for the glacier volume change. The $0^{\circ} \mathrm{C}$ isotherm elevation (based on mean May-September air temperatures) is estimated to have risen by about $250 \mathrm{~m}$ up to the upper parts of the glacier between 1948 and 2013. The glacier area exposed to melting during May to September almost increased by 1.8 -fold while the area reduced by a third since 1948 . Within a few years, the glacier area exposed to melting will decrease, leading the upper glacier parts under the $0^{\circ} \mathrm{C}$ isotherm while the snout will keep on retreating.
\end{abstract}

\section{Introduction}

As they are more sensitive to climate change, the small glaciers and ice caps currently contribute more to sea level rise than large ice sheets relative to their area (Paterson 1994; Meier et al. 2007; Gregory et al. 2013; Stocker et al. 2013). To estimate the glacier contribution to sea water level requires data of mass balance or glacier geometry change (Dyurgerov et al. 2010). In the Arctic, the dataset sources available to assess the long-term change of glaciers (in area and in volume) are quite rare, heterogeneous in nature and in accuracy and available for a period not exceeding a century (Stocker et al. 2013). Among the methods used to investigate glacier geometry change, remote sensing methods provide information from the Arctic scale (e.g. Rignot \& Kanagaratnam 
2006; Korona et al. 2009) to the local scale (e.g. Rees \& Arnold 2007), with the largest sources of error at the largest scale.

With $33,837 \mathrm{~km}^{2}$ of ice caps and glaciers, Svalbard is among the largest glaciated areas in the high Arctic (Radić et al. 2013). It has the largest density of glaciers monitored in the Arctic island zone defined by the World Glacier Monitoring Service (WGMS 2016). Along the west coast of Spitsbergen, the Brøgger Peninsula displays several small valley glaciers among which Midtre Lovénbreen (ML), Austre Lovénbreen (AL) and Austre Brøggerbreen (AB) have been studied since the 1960s (Corbel 1966; Corbel 1970; Hagen \& Liestøl 1990; Liestøl 1993; WGMS 2016). Recently, the investigations on these valley glaciers have been intensified (e.g. Rippin et al. 2003; Kohler et al. 2007; Murray et al. 2007; Rees \& Arnold 2007; Barrand et al. 2010; Mingxing et al. 2010; James et al. 2012). Most of these authors have shown a constant but irregular retreat of these glacier fronts since the end of the Little Ice Age (LIA).

The present paper investigates the changes in length, surface and volume of $\mathrm{AL}\left(78.87^{\circ} \mathrm{N}\right.$, $12.15^{\circ} \mathrm{E}$ ) over a long period (1948-2013), using measurements of front position and annual mass balance combined to several dataset sources: a digitized contour map, aerial photographs, satellite images and digital elevation models (DEMs). In addition, the Ny-Ålesund station ( $6 \mathrm{~km}$ west of the study area) provides climate data from 1969. By taking into account a catchment area constant since the LIA, we discuss the potential relation between the glacier geometry change (area, volume) and air temperature (AT) data. The long-term evolution is discussed, combining our mass balances obtained on the AL with those extrapolated from ML and AB following the observed close correlations with these two neighbouring glaciers. The paper also provides a discussion about consistency of methods used for assessing volume change of AL over 1962-2013. Then, in order to understand the ongoing shrinking rates, the evolution of the average $0^{\circ} \mathrm{C}$ isotherm over May-September is proposed and examined for seven dates between 1948 and 2013.

\section{General settings}

Svalbard, an archipelago with 55.5\% glacier cover, represents about $10 \%$ of the total Arctic small glaciers area (Liestøl 1993; Kohler et al. 2007; Radić et al. 2013). Similar to what is observed throughout the Arctic, this area is very reactive to climate change: Hagen et al. (2003) stated that all the small glaciers (area lower than $10 \mathrm{~km}^{2}$ ) have been clearly retreating since the end of the LIA. Small valley glaciers of the Brøgger Peninsula have thus lost both in mass and in area (Lefauconnier \& Hagen 1990; Hagen et al. 1993; Liestøl 1993; Lefauconnier et al. 1999; Kohler et al. 2007). In a recent study, Kohler et al. (2007) demonstrated that the average thinning rate of ML has increased steadily since 1936. They showed that the thinning rates from 2003 to 2005 were more than four times the average of the first period (1936-1962).

Regarding its climate, the Brøgger Peninsula is subject to the influence of the northern extremity of the warm North Atlantic current (Liestøl 1993). The climate at Ny-Ålesund (8 m a.s.l.) is of polar oceanic type with a mean annual air temperature (MAAT) of $-5.2^{\circ} \mathrm{C}$ and a total annual precipitation of $427 \mathrm{~mm}$ water equivalent (w.e.) for 1981-2010 (Førland et al. 2011). Over an earlier period (1961-1990), these parameters (Ny-Ålesund data for 1975-1990 and interpolated from Longyearbyen data before 1975$)$ were lower $\left(-6.3^{\circ} \mathrm{C}\right.$ for AT and $385 \mathrm{~mm}$ for precipitation), indicating that a significant climate change occurred over the last few decades (Førland et al. 2011).

The AL glacier is a small land-based valley glacier, $4 \mathrm{~km}$ long from South to North along the Brøgger Peninsula (Figure 1). The glacier area was $4.48 \mathrm{~km}^{2}$ in 2013 and its elevation ranges from 50 to $550 \mathrm{~m}$ a.s.l. Its catchment area spreads over $10.577 \mathrm{~km}^{2}$, taking into account an outlet where the main stream crosses a compact calcareous outcrop $400 \mathrm{~m}$ upstream from the coastline (Figure 1). The catchment is characterized by a proglacial area downstream and the glacier it-self upstream, surrounded by a series of rugged mountain peaks whose elevation reaches $880 \mathrm{~m}$ a.s.l. (Nobilefjellet). The first glaciological and hydrological investigations in the Brøgger Peninsula were conducted by 


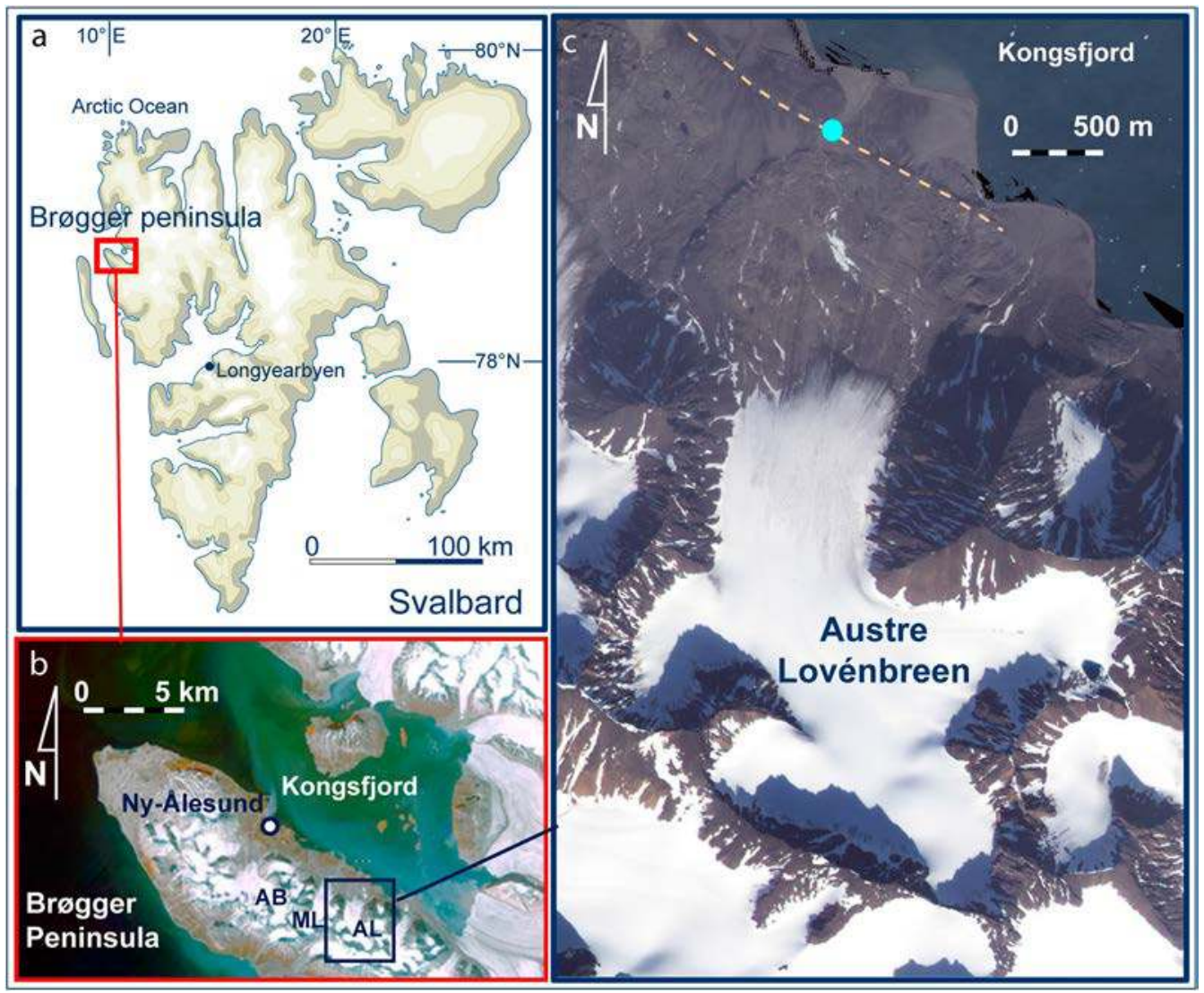

Figure 1. Location of Austre Lovénbreen within the Svalbard archipelago and the Brøgger Peninsula. AL: Austre Lovénbreen; ML: Midtre Lovénbreen; AB: Austre Brøggerbreen. On (c), the dashed line indicates the position of a calcareous, massive outcrop. The dot in (c) is the outlet considered for delineating the watershed boundaries of AL. Photo credits: (b) CNES and (c) Formosat images, NSPO, Distribution Airbus D\&S.

French scientists during the early 1960s on the Lovén glaciers. In 1965, Geoffray (1968) implemented a network of 17 stakes on AL. Preliminary hydro-glaciological investigations conducted by Vivian (1964) were pursued by Vincent and Geoffray (1970). Two decades later, Griselin $(1982,1985)$ proposed the first hydrological balance of the AL catchment. More recently Mingxing et al. (2010) published annual mass balance data for 2005-2006.

\section{Data and methods}

The techniques of airborne and satellite remote sensing combined with topographic data imported into a GIS database are relevant tools to investigate geometry changes of glaciers (Haakensen 1986; Rippin et al. 2003; Kohler et al. 2007; Rees \& Arnold 2007; Moholdt et al. 2010; Friedt et al. 2012). In addition, field measurements (GPS, snow drills, ice stake measurements, ground penetrating radar) are common complements to remote sensing techniques (Østrem \& Brugman 1991; Hock 2005; Brandt \& Kohler 2006; Mingxing et al. 2010; Saintenoy et al. 2013).

In the present paper, the change in AL geometry over the 1948-2013 period is investigated using (i) geodetic methods (a topographic map, aerial photos, satellite images, GPS tracks, airborne light detection and ranging [LIDAR]) and (ii) annual mass balance (Ba after Cogley et al. [2011]) measured from 2008 to 2015 . The source materials and data vary depending on whether the glacier change is studied in terms of length, area or volume change (Figure $2(a-f)$ ). 


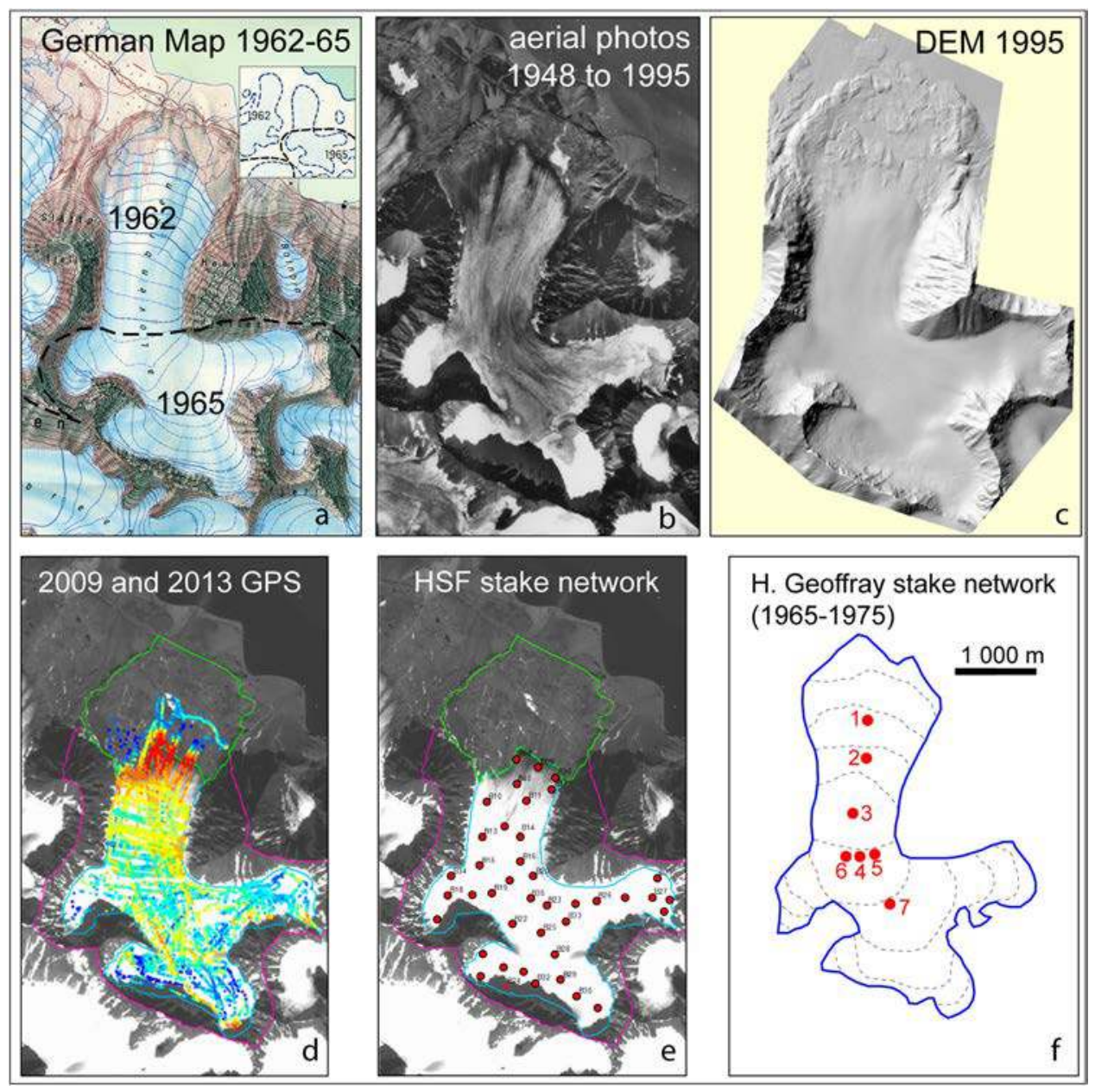

Figure 2. Documents and stake networks used to survey the Austre Lovénbreen geometry change. In (d) and (e), a line shows the upper AL watershed boundary and the downstream watershed boundary (i.e. the proglacial moraine limit upstream the outlet) and the line surrounding the glacier is the 2009 glacier limit. Photo credits: (a) extract from Pillewizer (1967), (b) and (c) Norsk Polar Institute and (d) and (e) Formosat images, NSPO, provided by Spot Image.

\subsection{Front position and area change}

- 1962-1965 German topographic map: East German scientists produced a 1/25,000 map from 1962 to 1965 (Pillewizer 1967) that we georeferenced (Figure 2(a)). In this paper, this dataset will be referred to as the '1962-1965 map' since the AL snout (elevation lower than $300 \mathrm{~m}$ a.s.l.) was mapped in 1962 and the higher part of the glacier (above $300 \mathrm{~m}$ a.s.l.) was mapped in 1965.

- Aerial photos: Six aerial stereographic photographs (Figure 2(b)) provided by the Norsk Polarinstitutt (NPI) were used to determine the glacier front position at different dates: 1948 (unknown scale), 1966 (scale of 1/50,000), 1971 (1/20,000 and 1/6,000), 1977 $(1 / 50,000), 1990(1 / 50,000$ and $1 / 15,000)$ and $1995(1 / 15,000)$. We georeferenced original aerial images with a GPS-referenced ground control points, at a density of approximately 1 point per $\mathrm{km}^{2}$ using relevant ground features on the surrounding ridges and in the glacier forefield. 
- Airborne and satellite data: For the period 1995-2008, the only available, dataset at high resolution was a 2005 Scott Polar Institute Airborne LIDAR DEM (Rees \& Arnold 2007). In this paper, it was only used to outline the front position in 2005 since the survey only covers AL glacier forefield and snout. A Formosat-2 image was used for 2009 (Friedt et al. 2012). Before 2006, multiple georeferenced Landsat7 images are available on the USGS website. Seven images $(1985,1989$, 1990, 1998, 1999, 2002 and 2006) were analysed but rejected due to a poor pixel definition $(30 \mathrm{~m} \times 30 \mathrm{~m})$. Additionally, on these Landsat7 images, we found the differentiation between the ice or snow-covered surfaces from rock or morainic material challenging, leading to an error of $\pm 100 \mathrm{~m}$ on the glacier front positioning.

- Front positioning by GPS: For the 2008-2013 period, the glacier front limit was surveyed every year at the end of September with a Coarse Acquisition GPS. When Formosat-2 images and GPS data were available for the same year, in situ GPS front positioning is considered more accurate.

Thus, a total of 14 AL front positions can be investigated over 1948-2013. The front positions were manually delineated for years between 1948 and 2005. After 2005, that is, for 2008-2013, the snout positions were determined by GPS. Since the margin is covered with rock debris and some residual ice may remain in the proglacial moraine, the actual glacier front is not always easy to delineate neither on images nor in the field. Even if the limit may also have changed in the upper part of the glacier, the available source materials are not precise enough to determine accurately any significant difference on the upper parts of the glacier (Bernard et al. 2014). This is due to (i) the steepness of surrounding slopes and/or (ii) the snow cover at the foot of slopes covering the rimaye (Bernard et al. 2013). We therefore used a single image as the reference to delineate the glacier area behind the snout (Formosat-2 image of summer 2009).

In a previous publication by our group, Friedt et al. (2012) analysed the error margin on the AL glacier limit position. Their results are consistent with the uncertainty analysis published by Rippin et al. (2003). As we used the same dataset sources as Friedt et al. (2012), the uncertainty analysis made in the paper remains valid here:

- the contour map and all airborne/satellite images were re-sampled on a $5 \mathrm{~m} \times 5 \mathrm{~m}$ grid;

- the glacier boundary analysis using manual colour identification (upper limit of the glacier for all years and snout position before 2008) yields a 2 pixel uncertainty, that is, an uncertainty of $\pm 10 \mathrm{~m}$ and

- GPS delineation of the snout (2008-2013) yields a horizontal uncertainty of $\pm 5 \mathrm{~m}$.

Such boundary position uncertainties yield a variable uncertainty on the glacier area (Table 1): considering that the glacier limit is largely constant upstream (our reference for all years being the 2009 glacier ice-rock interface; see the thick line on Figure 3) and that only the snout position is significantly evolving (see the length of glacier front in Table 1 and Figure 3), the area uncertainty is given by the sum of (i) the uncertainty on the upper glacier limit (length of $12.29 \mathrm{~km}$ times $10 \mathrm{~m}$ for all years) and (ii) the uncertainty on the independently measured snout position (the length of the front times $10 \mathrm{~m}$ for $1948-2005$ or times $5 \mathrm{~m}$ for 2008-2013).

\subsection{Volume change}

In order to assess the volume change of the glacier over 1962-2013 (51 years), we compared different dataset resources available for AL, all converted into DEMs: (i) the '1962-1965 map' (ii) the 1995 DEM (NPI) and (iii) 2 new DEMs produced from our GPS measurements in 2009 and 2013.

Other sources exist but, based on the elevation uncertainty analysis, only datasets exhibiting submeter standard deviation (SD) on the altitude were considered. Most significantly, we rejected: 


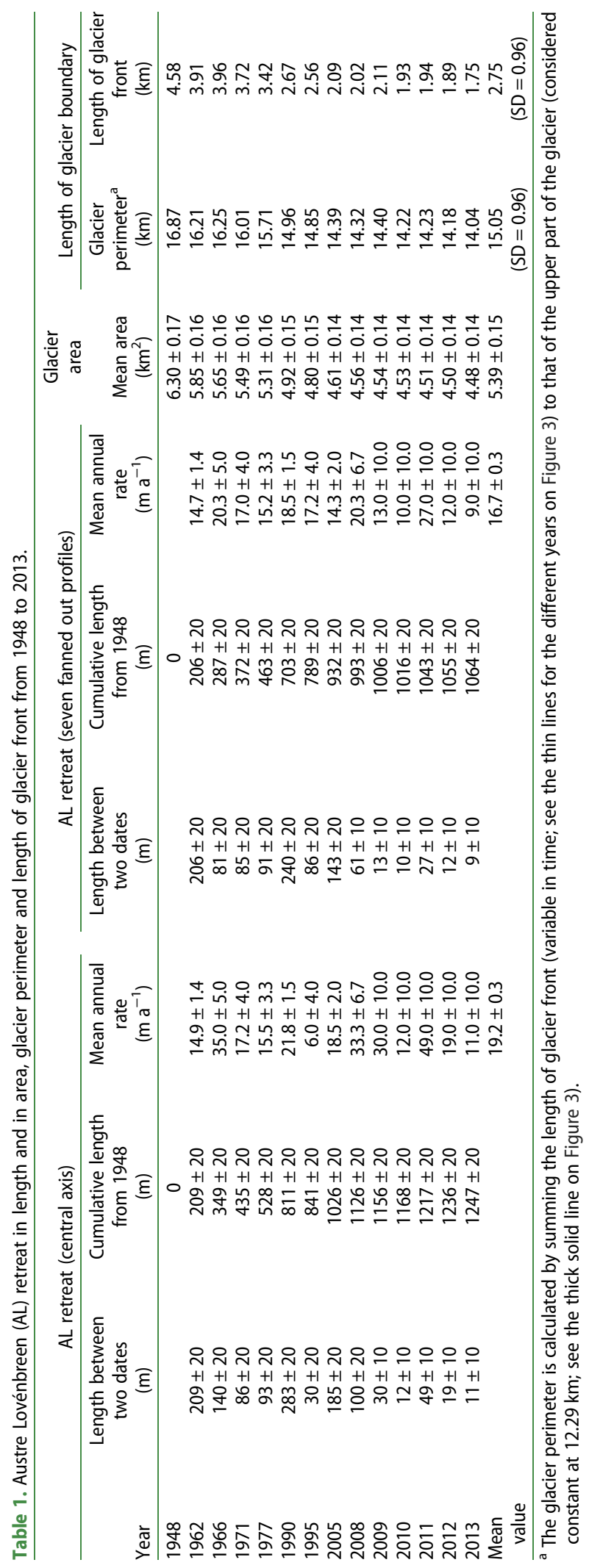




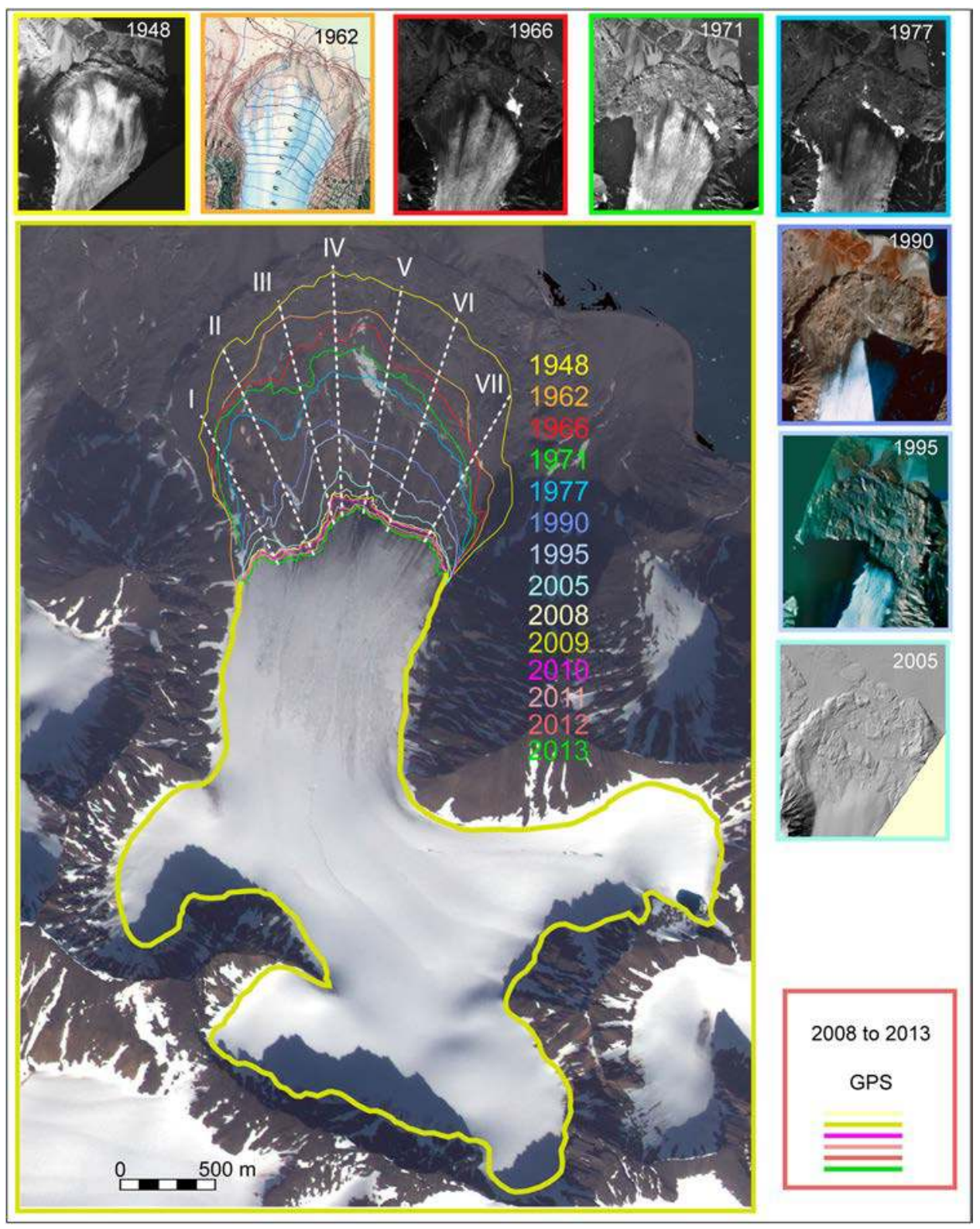

Figure 3. Front position of Austre Lovénbreen between 1948 and 2013. Outside the front area, since the change of the glacier limits were considered negligible, we used the limits visible on a Formosat-2 image of August 2009. Photo credits: Formosat, NSPO, provided by Spot Image. Aerial photos of 1948, 1966, 1971, 1977, 1990 \& 1995 provided by the Norsk Polar Institute. Extract of 1962 topographic map from Pillewizer (1967).

- the 2007 SPIRIT-derived DEM (SPOT5 stereoscopic survey of Polar Ice provided by CNESFrance in the frame of 2007-2009 IPY) due to a large elevation uncertainty (Korona et al. 2009);

- the 2006 DEM mentioned in Friedt et al. (2012) due to a poor coverage of some of the key areas of the catchment;

- the 2005 Scott Polar Institute DEM derived from a LIDAR survey (Rees \& Arnold 2007) which has $0.15 \mathrm{~m}$ vertical accuracy but only covering part of the studied catchment (the glacier forefield and the snout). 
Hence, the three periods investigated herein for assessing the volume change are 1962-1995, 1995-2009 and 2009-2013 (Figure 2):

- 1962-1965 German topographic map (Figure 2(a); Pillewizer 1967): Original 20 m contour line intervals were manually delineated in a vector format. Based on this linear elevation information, interpolation was performed to obtain a continuous DEM of the glacier surface. The elevation error was estimated by Friedt et al. (2012) by analysing DEM errors (mean and SD) in areas of the proglacial moraine known to be static over time: the resulting SD was stated as $3 \mathrm{~m}$. Cartographical approximations on the original map and computation artefacts were the source of cumulative errors (Friedt et al. 2012).

- 1995 DEM (Figure 2(c)): This DEM provided by the NPI was derived using analytical photogrammetry from six stereo-overlapping aerial photographs taken in August 1995 (Rippin et al. 2003; Kohler et al. 2007). According to Kohler et al. (2007) and Aas F. (personal communication), the DEM of 1995 has an elevation uncertainty within $\pm 1.5 \mathrm{~m}$.

- 2009 DEM and 2013 DEM (Figure 2(d)): Both DEMs were made by snowmobile carrying a dual-frequency GPS (Trimble Geo XH, Zephyr antenna) in order to obtain the glacier surface elevation in April 2010 and April 2014. The resulting dataset was post-processed for electromagnetic delay correction using reference Rinex correction files provided by the geodetic station located in Ny-Ålesund. Snow thickness interpolated from in-situ measurements (avalanche probe and PICO [University of Nebraska, Lincoln, U.S.A.] snow drill) made in April 2010 and 2014 was removed from the glacier surface elevation of April in order to provide the glacier elevation at the end of the 2009 and 2013 summers. These GPS-derived elevation models exhibit a SD on the elevation of $0.5 \mathrm{~m}$, including both measurement uncertainty and experimental procedure-related uncertainties.

When subtracting two DEMs, the uncertainty of elevation is assumed to be equal to the sum of elevation uncertainty of each image or map. It is therefore within $\pm 4.5 \mathrm{~m}$ between the '1962-1965 map' and 1995 photogrammetry-derived DEM, within $\pm 2.0 \mathrm{~m}$ uncertainty between the 1995 DEM and a GPS-derived DEM, within $\pm 1.0 \mathrm{~m}$ uncertainty between two GPS-derived DEMs and within $\pm 3.5 \mathrm{~m}$ uncertainty between the '1962-1965 map' and a GPS-derived DEM. The uncertainty on volume change is therefore the uncertainty of elevation times the mean glacier areas between two years.

\subsection{Mass balance}

Field measurements of ablation and accumulation have been made yearly using a 36-stake network that we set up in 2007 to cover the whole AL glacier surface (Figure 2(e)). Glacier-wide mass balance is computed from measurements conducted twice a year: at the end of winter (late April/early May) for winter mass balance (not used in this paper) and at the end of summer (late September/early October) for annual mass balance (Ba; after Cogley et al. 2011). The Ba were computed for eight years (from 2008 to 2015 meaning glaciological years 2007-2008 to 2014-2015). The AL Ba was obtained by inverse distance weighting interpolation of 36-stake measurements (Bernard et al. 2010; Bernard 2011).

All height measurements at stakes are independent and the uncertainty on the height measurement is estimated to be $\pm 0.05 \mathrm{~m}$. Thus, the uncertainty on $B$ a derived from subtracting independently measured stake heights is \pm 0.10 or $\pm 0.09 \mathrm{~m}$ w.e. (mean ice density of 0.9 ; e.g. Moholdt et al. 2010). This uncertainty considered on $B$ a is consistent with that given by Fountain and Vecchia (1999) for a glacier mass balance computed with about 30 stakes. The uncertainty of Ba averaged over a time period (year $i$-year $j$ ) is therefore the sum of the Ba uncertainty of each year (year $i$ and year $j$ ) divided by the number of years separating the years $i$ and $j$.

In addition, previous stake measurements for 1965-1975 were obtained once in 1975 by Brossard and Joly (1986) at 7-stakes retrieved on the snout from the 17-stake network installed in 1965 (Geoffray 1968) (Figure 2(f)). 
The longest $\mathrm{Ba}$ time series in the Brøgger peninsula concern two other glaciers: (i) ML, the neighbouring glacier of $\mathrm{AL}$ and (ii) $\mathrm{AB}, 6 \mathrm{~km}$ further West (Figure 1). In this paper, we use the $B \mathrm{a}$ of $\mathrm{ML}$ between 1968 and 2007 provided by WGMS (2016). The ML Ba were computed by averaging 10stake measurements within $100 \mathrm{~m}$ elevation bins along the central line (Barrand et al. 2010). For 1963-1967, we used the AB Ba data given by Lefauconnier and Hagen (1990). Before 1967, these authors estimated $\mathrm{AB} B$ a from positive AT of July-September recorded at Longyearbyen combined to winter precipitation for which coefficient correlation is 0.90 .

\subsection{Air temperature}

AT time series are recorded since 1969 at the Ny-Ålesund station at $8 \mathrm{~m}$ a.s.l. (eKlima 2013). The AT over AL was deduced by applying an altitude, AT gradient to the $\mathrm{Ny}$-Ålesund AT data. The gradient was established from daily AT obtained from two temperature loggers (Hobo pro V2 U23-004 Onset Hobo data loggers, Bourne, MA, U.S.A.; accuracy of $\pm 0.2^{\circ} \mathrm{C}$ ) installed on the AL: one downstream at $148 \mathrm{~m}$ a.s.l and the other upstream at $481 \mathrm{~m}$ a.s.l. The resulting average altitude, AT $\left(-0.005^{\circ} \mathrm{C} \mathrm{m}^{-1}\right.$ for May-September) is consistent with the literature (e.g. Corbel 1966; Geoffray 1968; Corbel 1970; Griselin 1982; Griselin \& Marlin 1999 for AL; Joly 1994 for ML). Additionally, a third similar temperature logger was set in the AL proglacial moraine at $25 \mathrm{~m}$ a.s.l.: the mean annual difference of $0.007^{\circ} \mathrm{C}$ lower than the accuracy on temperature measurement indicates that no significant longitudinal gradient exists between $\mathrm{Ny}$-Ålesund and the AL catchment, $6 \mathrm{~km}$ further East.

\section{Results}

\subsection{AT data}

In this paper, we consider hydro-glaciological years from October 1 to September 30 in order to compare AT data with $B$ a that is measured at the end of September/beginning of October each year. Over 1970-2013 (meaning glaciological years from 1969-1970 to 2012-2013), the MAAT in Ny-Ålesund was $-5.22^{\circ} \mathrm{C}$ (SD of $1.27^{\circ} \mathrm{C}$ ). Over the period, the MAAT displays a positive temporal trend of $+0.57^{\circ} \mathrm{C} /$ decade (Figure 4 ). This is in agreement with the data analysed by Førland et al. (2011) for Svalbard. The segmented linear regression technique explained by Oosterbaan (1994) was applied to find potential breakpoints in the MAAT time series. The result is the following: the MAAT time series is statistically analysed as a period of constant temperature followed by a period of uniform temperature increase with a breakpoint between 1994 and 1995 (98\% confidence interval): this temperature change occurring in the mid-1990s may be relevant to understand glacier volume evolution. During the first 25 years (1970-1994), there is no clear temporal trend $\left(+0.04^{\circ} \mathrm{C}\right.$ per decade) as opposed to the following 19 years (1995-2013) for which the MAAT significantly increases with a trend of $+1.38^{\circ} \mathrm{C} /$ decade. This $1995-2013$ gradient is 2.4 times the average gradient calculated over the whole period (1970-2013). The MAAT value is $-4.45^{\circ} \mathrm{C}\left(\mathrm{SD}\right.$ of $1.12^{\circ} \mathrm{C}$ ) over $1995-2013$.

Mean summer air temperature (MSAT) was also calculated for May-September as an indicator of the melting period at $\mathrm{Ny}$-Ålesund: it was $+1.88^{\circ} \mathrm{C}\left(\mathrm{SD}\right.$ of $\left.0.71^{\circ} \mathrm{C}\right)$ for $1970-2013$. Using the segmented linear regression technique (Oosterbaan 1994), the MSAT may be also separated into two periods with a statistically significant breakpoint between 1996 and 1997: the trend over 1970-2013 was $+0.34^{\circ} \mathrm{C} /$ decade (trends of $+0.10^{\circ} \mathrm{C} /$ decade for $1970-1996$ and $+0.90^{\circ} \mathrm{C} /$ decade for $1997-2013$; Figure 4). The mean MSAT value was $+1.57^{\circ} \mathrm{C}\left(\mathrm{SD}\right.$ of $0.59^{\circ} \mathrm{C}$ ) for $1970-1996$ and increased to $+2.37^{\circ} \mathrm{C}\left(\mathrm{SD}\right.$ of $0.59^{\circ} \mathrm{C}$ ) for $1997-2013$ (Figure 4 ).

\subsection{AL length change}

Between 1948 and 2013, AL front showed clear changes (Figure 3). The recession was not however equally distributed over the front (Figure 3). A maximum retreat distance may be estimated along the 


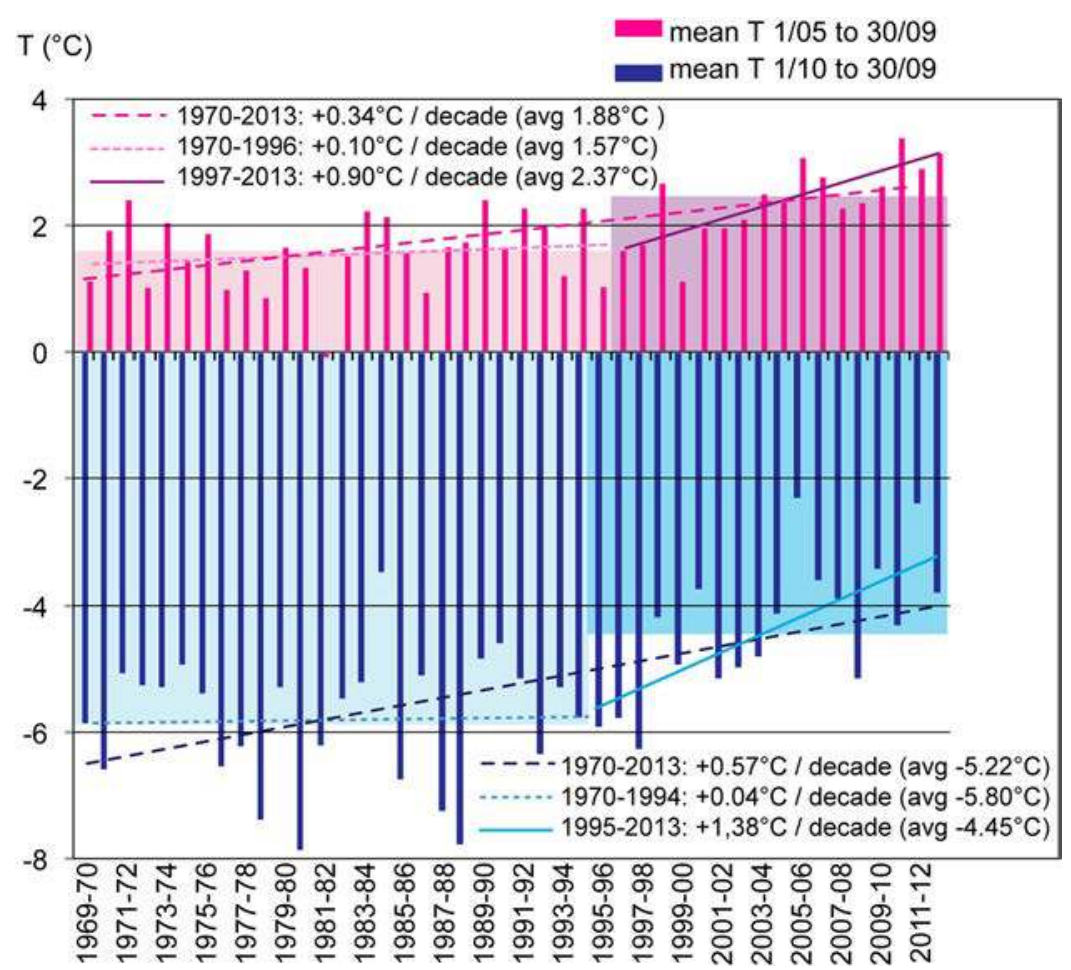

Figure 4. MAAT and mean summer MSAT in Ny-Ålesund for 1970-2013. The data are given in hydrological years, that is, from October 1 to September 30. Summer is considered from May 1 to September 30.

central flow line with a total recession of $1247 \pm 20 \mathrm{~m}$ between 1948 and 2013, that is, a mean retreat rate of $-19.2 \pm 0.3 \mathrm{~m} \mathrm{a}^{-1}$ (Table 1). Seven fanned out profiles (Figure 3) were arbitrarily yet regularly selected to assess the variability of the glacier retreat due to irregularities in the underlying bedrock. The results indicate a mean retreat rate of $-16.7 \pm 0.3 \mathrm{~m} \mathrm{a}^{-1}$ between 1948 and 2013 with rate ranges from $-12.8 \pm 0.3 \mathrm{~m} \mathrm{a}^{-1}$ on the western part to $-19.2 \pm 0.3 \mathrm{~m} \mathrm{a}^{-1}$ in the central axis (Table 1; Figure 3). Figure 5(a) shows a regular retreat, linear with time, for the average of the seven fanned out profiles whereas an increase of the retreat rate from 2005 is noticeable for the central one. The retreat rate range is consistent with that indicated for the central line of ML, that is, $-15 \mathrm{~m} \mathrm{a}^{-1}$ (Hansen 1999). Even if investigated over a short period (one-year interval), Mingxing et al. (2010) mentioned a similar value for the mean annual AL retreat rate $\left(-21.8 \mathrm{~m} \mathrm{a}^{-1}\right.$ for $\left.2005-2006\right)$.

In details, the annual retreat rate displayed a wide range of values (Table 1). Mingxing et al. (2010) also mentioned great differences in the AL retreat rates along the central glacier flowline (from -2.8 to $-77.3 \mathrm{~m} \mathrm{a}^{-1}$ for $2005-2006$ ).

The important spatio-temporal variability is mostly linked to differences in ice thickness and in bedrock morphology. Moreover glacier length change is partly compensated for by glacier flow (Vincent et al. 2000). Mingxing et al. (2010) measured the surface ice flow velocity of AL using differential GPS, they obtained a mean velocity of $2.5 \mathrm{~m} \mathrm{a}^{-1}$ along the central line of the AL snout, consistent with a velocity of $4 \mathrm{~m} \mathrm{a}^{-1}$ given by Rees and Arnold (2007) for 2003-2005 for the ML also along the central line. The velocity is at least five times lower than the glacier margin retreat rate.

\subsection{AL area change}

In this paper, the change in area (Table 1 and Figure 5(b)) only shows the reduction of the snout area since the same upper limit of the glacier (measured in 2009) was considered constant for all years. 


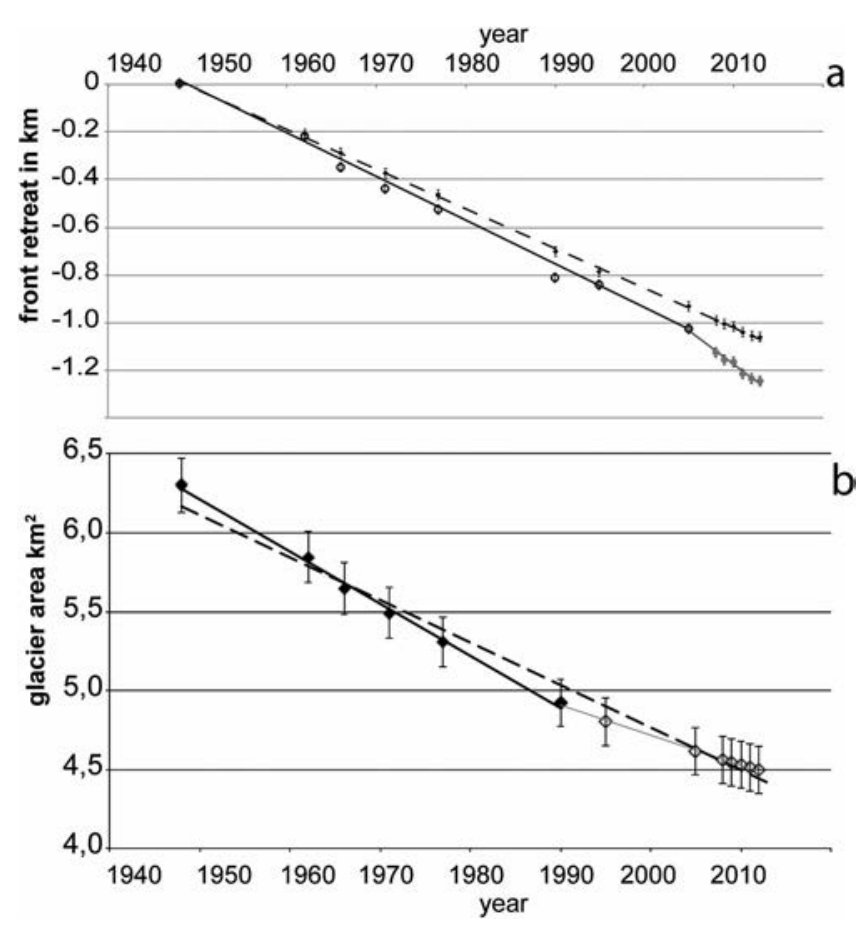

Figure 5. Austre Lovénbreen length and area changes over 1948-2013. (a) The length reduction versus time. The dashed line is derived best-fit line of the average of seven profiles (slope of $-16.4 \mathrm{~m} \mathrm{a}^{-1}$ ) and the solid line is for the mean central flowline (slope of $\left.-19.3 \mathrm{~m} \mathrm{a}^{-1}\right)$. (b) The area reduction versus time. The black, dashed is the derived best-fit line of all datapoints $\left(-0.027 \mathrm{~km}^{2} \mathrm{a}^{-1}\right.$ for 1948-2013) segmented into two lines by a breakpoint between 1990 and $1995\left(-0.032 \mathrm{~km}^{2} \mathrm{a}^{-1}\right.$ for $1948-1995$ and $-0.018 \mathrm{~km}^{2} \mathrm{a}^{-1}$ for $\left.1995-2013\right)$.

Therefore, the glacier area is likely to be underestimated before 2009 and slightly overestimated after 2009. The results obtained for the area change of AL indicate that in 2013 the glacier covered $71 \%$ of its 1948 area. In other words, in 2013, the glacier covered only $42 \%$ of the total basin area $\left(10.577 \mathrm{~km}^{2}\right)$, whereas it occupied $60 \%$ of the catchment in the late $1940 \mathrm{~s}$.

The glacier area data plotted over time in Figure 5(b) indicate a progressive temporal decrease (fit resulting from minimizing quadratic error) with an average reduction rate over 1948-2013, similarly to $1962-2013$ (Table 2). An uncertainty of $\pm 0.002 \mathrm{~km}^{2} \mathrm{a}^{-1}$ is obtained on the slope by computing the uncertainty on the slope of the regression 'glacier area upon time', which is the SD of the slope times a variable following Student's distribution for a 95\% confidence interval (Oosterbaan 1994). The uncertainty is less than $10 \%$ of the observed temporal trend.

Figure 5(b) shows that the area change with time has two periods of regular decrease separated by a perceptible breakpoint between 1990 and 1995: the gradient decreased from $-0.033 \pm$ $0.003 \mathrm{~km}^{2} \mathrm{a}^{-1}$ for $1948-1995$ (similar to $-0.032 \pm 0.003 \mathrm{~km}^{2}$ for $1962-1995$ ) to $-0.018 \pm$ $0.005 \mathrm{~km}^{2} \mathrm{a}^{-1}$ for $1995-2013$ (Table 2).

\subsection{AL volume change determined by DEM differences}

The AL change in volume was estimated by subtracting two by two 4 DEMs covering the 1962-2013 period that we can separate into three sub-periods: 1962-1995, 1995-2009 and 2009-2013 (Figure 6 and Table 2). For the whole 1962-2013 period, the total glacier ice volume loss was estimated at $129.1 \pm 18.1 \times 10^{6} \mathrm{~m}^{3}$ (Table 2). This corresponds to an average reduction rate of $-2.5 \pm 0.4 \times$ $10^{6} \mathrm{~m}^{3} \mathrm{a}^{-1}$ (the ratio of the volume divided by 51 years) or an average elevation difference of 


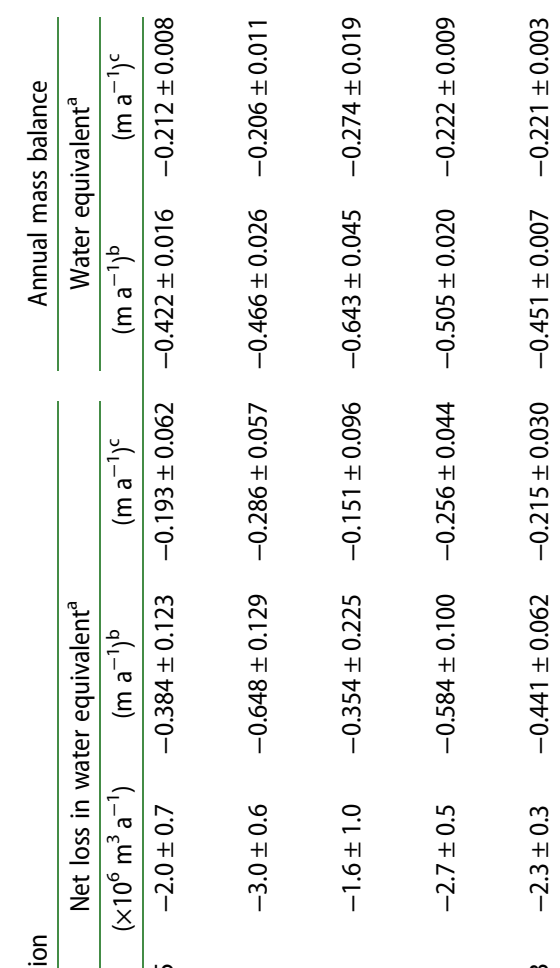

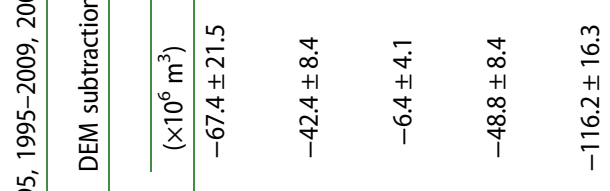

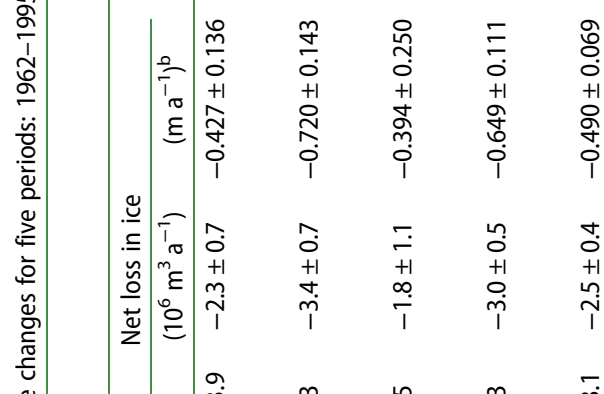

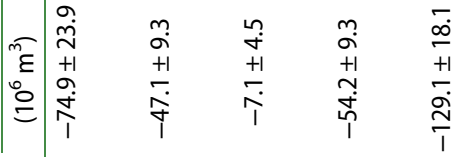

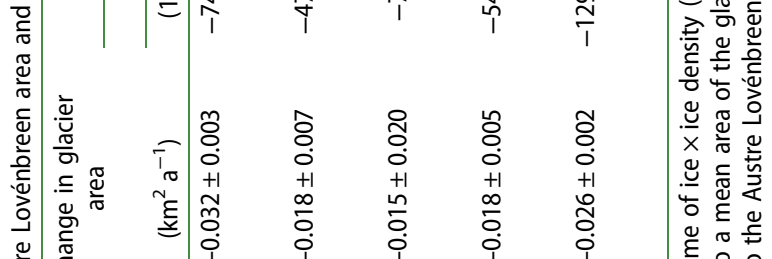

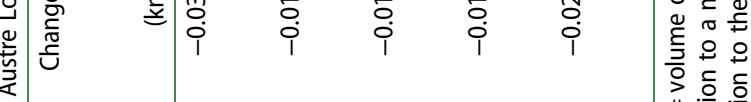




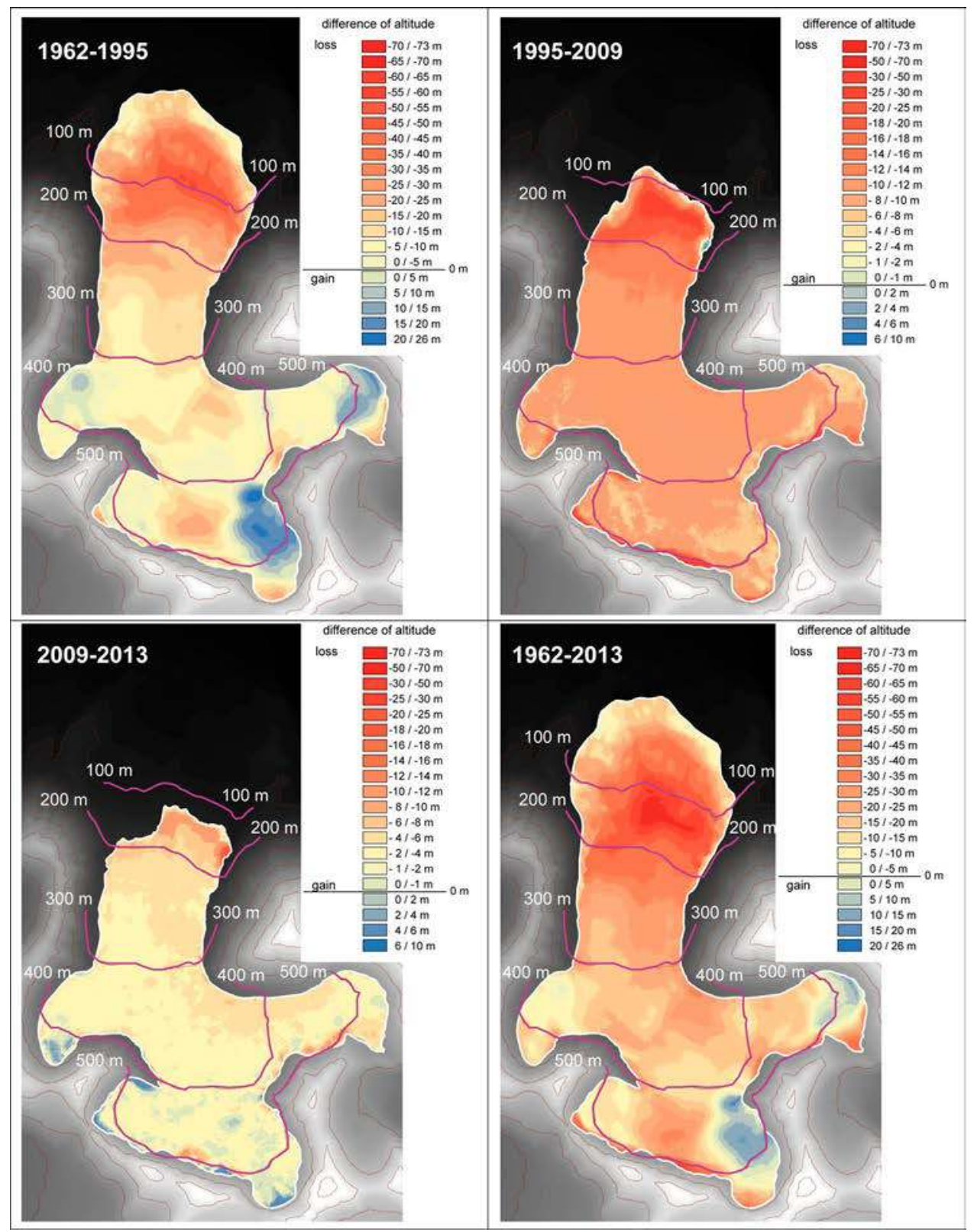

Figure 6. Maps of DEM differences of Austre Lovénbreen for four periods: 1962-1995, 1995-2009, 2009-2013 and 1962-2013. For 2009-2013, the scale is different than that of the three other maps since the change of altitude for four years is very low.

$-0.490 \pm 0.069 \mathrm{~m} \mathrm{a}^{-1}$ (ratio of $-2.5 \times 10^{6} \mathrm{~m}^{3} \mathrm{a}^{-1}$ by the average glacier area between 1962 and 2013, i.e. $5.17 \mathrm{~km}^{2}$ ).

The annual volume change rate is not constant between the three investigated periods:

- $-2.3 \pm 0.7 \times 10^{6} \mathrm{~m}^{3} \mathrm{a}^{-1}(1962-1995)$. The average elevation difference was $-0.427 \pm 0.136 \mathrm{~m} \mathrm{a}^{-1}$ (based on the average 1962-1995 glacier area, $5.32 \mathrm{~km}^{2}$ );

- $-3.4 \pm 0.7 \times 10^{6} \mathrm{~m}^{3} \mathrm{a}^{-1}(1995-2009)$. In terms of elevation difference, the rate was $-0.720 \pm$ $0.143 \mathrm{~m} \mathrm{a}^{-1}$ based on an average $1995-2009$ glacier area $\left(4.67 \mathrm{~km}^{2}\right)$ and 
- $-1.8 \pm 1.1 \times 10^{6} \mathrm{~m}^{3} \mathrm{a}^{-1}$ (2009-2013). Expressed as elevation difference, the rate was $-0.394 \pm$ $0.250 \mathrm{~m} \mathrm{a}^{-1}$ based on an average $2009-2013$ glacier area $\left(4.51 \mathrm{~km}^{2}\right)$.

For this last period, we see that the uncertainty accounts for two-third of the calculated net ice loss. As already shown by Friedt et al. (2012), a four-year interval is clearly too short to accurately determine the glacier volume change but only the DEMs of 2009 and 2013 were surveyed with the same instrument (GPS) and methods, in the frame of this study. To reduce the uncertainties, the two last periods (1995-2009 and 2009-2013) were gathered and gave a net ice loss of $-3.0 \pm 0.5 \times 10^{6} \mathrm{~m}^{3} \mathrm{a}^{-1}$ for the whole period. Expressed as elevation difference, the rate was $-0.649 \pm 0.111 \mathrm{~m} \mathrm{a}^{-1}$ with respect to an average $1995-2013$ glacier area $\left(4.64 \mathrm{~km}^{2}\right)$.

Using a mean ice density of 0.9 (e.g. Moholdt et al. 2010), AL lost $-2.3 \pm 0.3 \times 10^{6} \mathrm{~m}^{3} \mathrm{a}^{-1}$ w.e. during 1962-2013. The loss was $-2.0 \pm 0.7$ and $-2.7 \pm 0.5 \times 10^{6} \mathrm{~m}^{3}$ w.e. $\mathrm{a}^{-1}$ for $1962-1995$ and 1995-2013, respectively (Table 2).

\subsection{AL mass balance}

The AL Ba was measured yearly for 2008-2015 (Figure 7; Table 3). The average Ba was $-0.421 \pm$ $0.030 \mathrm{~m}$ w.e. $\mathrm{a}^{-1}$ for $2008-2015$. The high SD $\left(0.439 \mathrm{~m}\right.$ w.e. $\left.\mathrm{a}^{-1}\right)$ reflected a high interannual variability of $\mathrm{Ba}$. With the exception of 2014, all $\mathrm{Ba}$ were negative with considerable contrasts between years: from $+0.010 \pm 0.090 \mathrm{~m}$ w.e. (2014) to $-1.111 \pm 0.090 \mathrm{~m}$ w.e. (2013). The accumulation area ratio (AAR after Dyurgerov et al. [2009]; AAR is calculated as the accumulation area/total glacier area ratio) ranged from 0.00 to 0.66 over $2008-2015$.

Earlier studies of the AL catchment (Geoffray 1968; Griselin 1982) did not provide data to establish past $B$ a since the seven available data were located in the ablation area only. Between 1965 and 1975 the point mass balance ( $b a$ ) of the partial Geoffray's stake network spatially ranged from $-1.05 \mathrm{~m} \mathrm{a}^{-1}$ downstream to $-0.24 \mathrm{~m} \mathrm{a}^{-1}$ upstream (Table 4; Brossard \& Joly 1986). They fall within the same range as the 1962-1995 DEM subtraction at these same seven points (from -0.17 to $-1.09 \mathrm{~m} \mathrm{a}^{-1}$; Table 4 ).

So, in order to estimate the past AL Ba for 1967-2007, we correlated AL versus ML Ba data, both series having eight years in common (2008-2015). We obtained a strong correlation between the Ba series for 2008-2015, with a linear fit yielding the following equation (Figure 8(a)):

$$
B \mathrm{a}(\mathrm{AL})=1.136 \times \mathrm{Ba}(\mathrm{ML})-0.014(n=8 ; r=0.992),
$$

where $B$ a were given in $\mathrm{m}$ w.e.

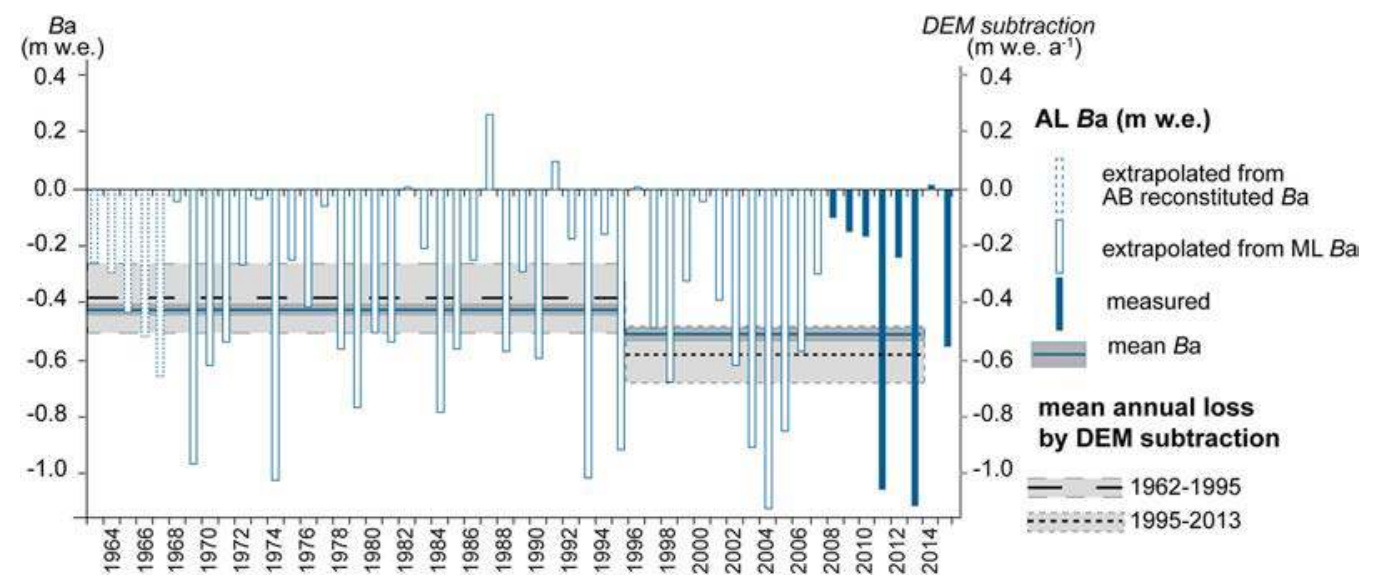

Figure 7. Time series of $A L$ annual mass balances from $A L$ measurements (dark) and reconstituted from mass balances from the $M L$ (solid light) and from $A B$ (dashed light). The average values of both $A L B a$ and DEM subtraction are also indicated with error bars (grey rectangles). 
Table 3. Austre Lovénbreen annual mass balances and AAR for 2008-2015. The uncertainty on $B a$ is $\pm 0.10 \mathrm{~m}$ in ice, $\pm 0.09 \mathrm{~m}$ w.e. and $\pm 0.04 \mathrm{~m}$ w.e. with respect to catchment area.

\begin{tabular}{|c|c|c|c|c|}
\hline \multirow[b]{2}{*}{ Year } & \multicolumn{3}{|c|}{ Annual mass balance, $B a(m)$} & \multirow[b]{2}{*}{ AAR } \\
\hline & Ice in relation to glacier area $^{a}$ & $\begin{array}{c}\text { Water equivalent in relation } \\
\text { to glacier area }{ }^{a}\end{array}$ & $\begin{array}{l}\text { Water equivalent in relation to } \\
\text { catchment area }{ }^{b}\end{array}$ & \\
\hline 2008 & -0.115 & -0.104 & -0.045 & 0.66 \\
\hline 2009 & -0.164 & -0.148 & -0.063 & 0.33 \\
\hline 2010 & -0.183 & -0.165 & -0.071 & 0.45 \\
\hline 2011 & -1.170 & -1.053 & -0.451 & 0.00 \\
\hline 2012 & -0.267 & -0.241 & -0.103 & 0.39 \\
\hline 2013 & -1.233 & -1.111 & -0.475 & 0.00 \\
\hline 2014 & +0.011 & +0.010 & +0.004 & 0.62 \\
\hline 2015 & -0.613 & -0.552 & -0.236 & 0.05 \\
\hline \multicolumn{5}{|l|}{ Mean } \\
\hline $2010-2013$ & -0.713 & -0.643 & -0.274 & 0.21 \\
\hline $2008-2015$ & -0.468 & -0.421 & -0.180 & 0.31 \\
\hline
\end{tabular}

${ }^{a}$ Glacier area of $4.53 \mathrm{~km}^{2}$ (mean 2008-2013).

b $10.577 \mathrm{~km}^{2}$.

By applying Equation (1) to the series of ML $B a$, we obtained an AL Ba time series extrapolated for 1968-2007 (Figure 7). Since Ba were not available for ML prior to 1968, we used the estimated Ba values computed by Lefauconnier and Hagen (1990) for AB. Subsequently, the strong correlation between $\mathrm{AB}$ and ML (Equation (2); Figure 8(b)) enabled AL Ba series to be calculated for 1963 -1967 (Figure 7) using again Equation (1) between AL and ML.

$$
B \mathrm{a}(\mathrm{ML})=0.9959 \times B \mathrm{a}(\mathrm{AB})+0.069(n=21 ; r=0.994),
$$

where $B \mathrm{a}$ are given in $\mathrm{m}$ w.e.

For extrapolated AL $B \mathrm{a}$, error bars are driven by the ML error bar $( \pm 0.25 \mathrm{~m}$ according to Kohler et al. 2007) times the regression coefficient, with uncertainty on each regression coefficient bringing a negligible contribution since $r$ is close to 1 (see the equations in Oosterbaan 1994). Hence, we assessed uncertainties of $\pm 0.26 \mathrm{~m}$ w.e. for each AL extrapolated Ba between 1968 and 2007 and $\pm 0.28 \mathrm{~m}$ w.e. between 1963 and 1967 (95\% confidence interval).

The average $1963-2013 \mathrm{Ba}$ was $-0.451 \pm 0.007 \mathrm{~m}$ w.e. $\mathrm{a}^{-1}$ with $-0.422 \pm 0.016 \mathrm{~m}$ w.e. $\mathrm{a}^{-1}$ for 1963-1995 and $-0.505 \pm 0.020 \mathrm{~m}$ w.e. $\mathrm{a}^{-1}$ for 1996-2013 (Table 2). The whole AL Ba time series (1963-2013) showed a negligible increase in the temporal trend of $-0.0026 \mathrm{~m}$ w.e. $\mathrm{a}^{-1}$. We observed that very negative $B a$ of AL such as in 2011 or 2013 (more than twice the average Ba) were not exceptional since they occurred eight times during 1963-2015 (Figure 7).

Table 4. Net mass balance (1965-1975 and 2008-2013) and DEM subtraction (1995-1962 and 2013-1995) of Austre Lovénbreen at the locations of the seven stakes of Geoffray (1968).

\begin{tabular}{|c|c|c|c|c|c|c|c|}
\hline \multicolumn{4}{|c|}{ Net mass balance } & \multicolumn{4}{|c|}{ DEM subtraction } \\
\hline \multirow[b]{2}{*}{ Stake ID ${ }^{\mathrm{a}}$} & \multirow{2}{*}{$\begin{array}{c}(\mathrm{m}) \\
1965-1975^{\mathrm{b}}\end{array}$} & \multicolumn{2}{|c|}{$\left(m a^{-1}\right)$} & \multicolumn{2}{|c|}{ (m) } & \multicolumn{2}{|c|}{$\left(\mathrm{m} \mathrm{a}^{-1}\right)$} \\
\hline & & $1965-1975^{b}$ & $2008-2013^{c}$ & $1995-1962^{c}$ & $2013-1995^{c}$ & $1995-1962^{c}$ & $2013-1995^{c}$ \\
\hline 1 & -10.5 & -1.05 & -2.47 & -36 & -34 & -1.09 & -1.90 \\
\hline 2 & -7.75 & -0.78 & -1.65 & -20 & -18 & -0.59 & -1.02 \\
\hline 3 & -5.55 & -0.56 & -0.95 & -12 & -12 & -0.35 & -0.69 \\
\hline 4 & -4.95 & -0.50 & -0.70 & -9 & -10 & -0.29 & -0.55 \\
\hline 5 & -4.75 & -0.48 & -0.81 & -11 & -12 & -0.34 & -0.65 \\
\hline 6 & -4.70 & -0.47 & -0.60 & -6 & -10 & -0.17 & -0.55 \\
\hline 7 & -2.35 & -0.24 & -0.57 & -12 & -8 & -0.35 & -0.43 \\
\hline Mean & -5.79 & -0.58 & -1.11 & -15.1 & -14.9 & -0.45 & -0.83 \\
\hline
\end{tabular}

\footnotetext{
${ }^{a}$ Location in Figure 2.

${ }^{b}$ After Geoffray's stake network (1968) and Brossard and Joly (1986).

c This study.
} 

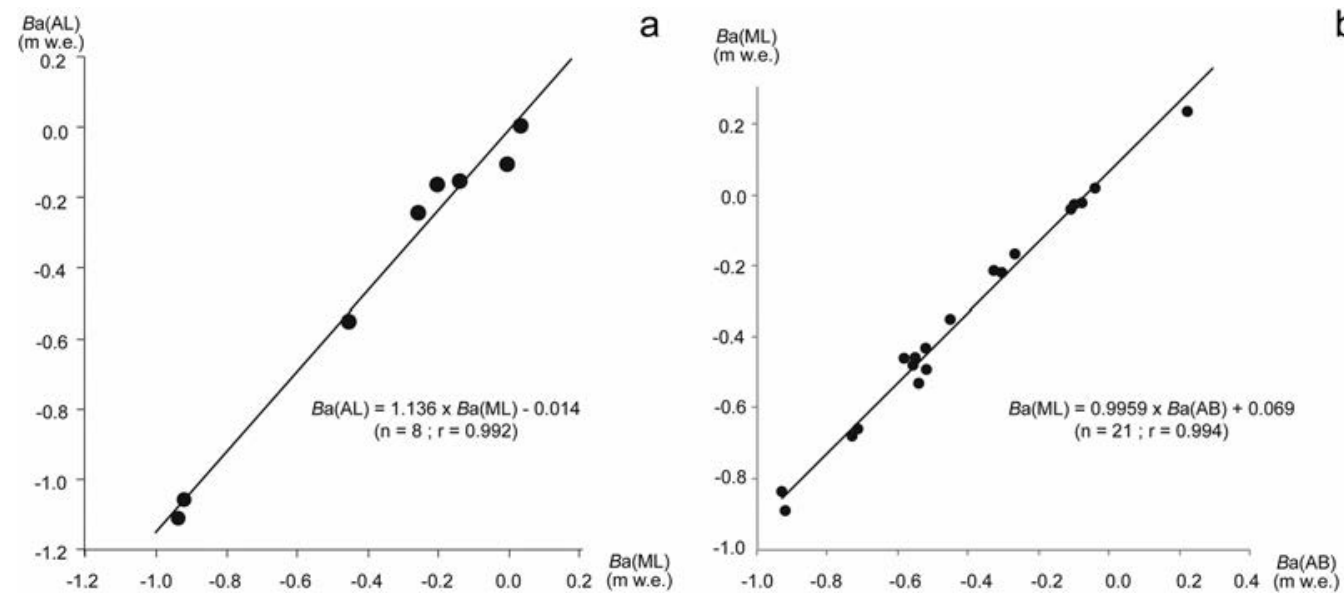

Figure 8. Correlation between annual mass balances between AL and two glaciers of the Brøgger peninsula: Austre Lovénbreen (AL) versus $M L$ for 2008-2015 (a) and ML versus AB for 1968-1988.

\section{Discussion}

During the 1948-2013 period, AL underwent changes of geometry (length, area and volume). The following discussion addresses (i) the change rates through time, (ii) the differences between the methods to estimate the change in volume (Ba versus DEM) and (iii) the relationship between geometry change and evolution of glacier areas exposed to melting.

\subsection{Variations in rate of AL retreat (length, area) for 1948-2013}

Whatever the resource type used to estimate the glacier retreat in length or in area through time (Figure 5(a,b)), we observed a strong linear fit. However, it was not possible to assess the changes in glacier higher in the catchment for reasons explained in Section 3.1.

The mean retreat calculated by averaging the length along seven profiles was relatively constant in time (Figure 3). A straight line with a mean slope of $-16.7 \pm 0.3 \mathrm{~m} \mathrm{a}^{-1}(n=14$ and $r=1.000)$ is representative of the average retreat rate of the glacier terminus. It is notable that the average AL velocity (2.5 $\mathrm{m} \mathrm{a}^{-1}$ according to Mingxing et al. 2010) does not exceed the average front retreat rate along the main flow line which is quite homogeneous over 1948-2013 $\left(-19.2 \pm 0.3 \mathrm{~m} \mathrm{a}^{-1} ; n=14\right.$ and $r=$ 0.997).

On the retreat rate versus time relationship determined for the central line (Figure 5(a)), the breakpoint in 2005 is not the consequence of a climatic change but illustrates the local predominance of the surrounding terrain topography in the apparent acceleration of the axial retreat. Averaging over seven profiles smooths out bedrock topographic features and yields a homogeneous retreat rate rather constant in time.

Regarding the glacier area, the average change was $-0.027 \pm 0.002 \mathrm{~km}^{2} \mathrm{a}^{-1}$ over $1948-2013(n=$ 14 and $r=0.993$ ). A slowdown in the area reduction was observed between 1990 and 1995 (Figure 5 (b)). This breakpoint may be surprising when considering the MAAT or MSAT series (Figure 4): the AT gradient increased after 1994, whereas the reduction rate of the glacier area slowed down. This apparent divergence may be partially explained by the reduction of the glacier terminus exposed to melting. We can observe that, in 1948, the glacier terminus was widely spread out in the glacier forefield uphill the LIA terminal moraine (Figure 3). Compared to 2013, the glacier terminus was less thick and the front itself was rather flat because it was not constrained by the surrounding terrain (Figure 9). In the present-day configuration, the glacier snout clearly is constrained on its eastern and western sides by the steep slopes of the glacier basin valley. The glacier snout gradually became 


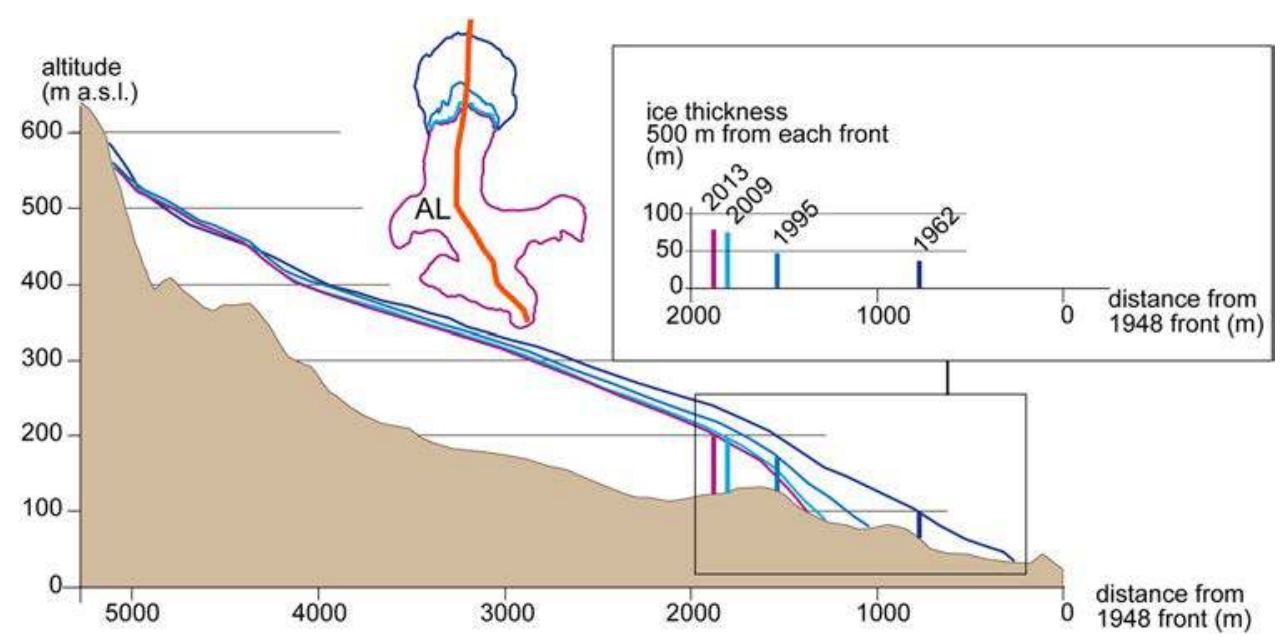

Figure 9. Cross-sections of the glacier along the central flowline (Austre Lovénbreen) in 1962, 1995, 2009 and 2013. The upper insert gives the ice thickness at a distance of $500 \mathrm{~m}$ from the AL front of 1962, 1995, 2009 and 2013 respectively.

thicker and its front steeper over time (Figure 9). If we compare the ice thicknesses at the glacier snout at a same distance from the respective fronts of 1962, 1995, 2009 and 2013, we highlight the increasing values of ice thickness: $35,45,72$ and $76 \mathrm{~m}$ at $500 \mathrm{~m}$ and $70,116,123$ and $124 \mathrm{~m}$ at $1000 \mathrm{~m}$ from the front of 1962, 1995, 2009 and 2013, respectively. Further discussion about the glacier areas exposed to melting is given below inSection 5.5.

Even if the changes of snout length as well as glacier area are two convenient, visible proxies to study glacier dynamics, they may be delicate to interpret since they combine several processes that are not only dependent on climate conditions. Glacier shrinkage is also related to parameters including ice thickness, glacier velocity, basal thermal state of glacier, topography and roughness of underlying bedrock and geological structures (slope and fractures). Therefore, to assess glacier changes, glaciological investigations have to focus on volume in addition area or length of glaciers.

\subsection{Variation in volume (reduction rate and percentage of total AL volume) for 1962-2013}

Regarding the methods for assessing the volume change of the glacier, it could be hazardous to compare heterogeneous sources of dataset since investigating the long-term change of glacier often requires the use of various documents (maps, aerial photos, satellite and airborne images) with different accuracies and scales. In the case of AL, great care was applied to minimize data artefacts but oldest sources showed some discrepancies from expected trends. For the 2009 and 2013 datasets, the DEM difference produced by Rinex-post-processed GPS measurements is expected to lead to the best accuracy of our datasets but such a short time interval actually yields unacceptable signal to noise ratio $\left(64 \%\right.$, i.e. an error of $0.25 \mathrm{~m} \mathrm{a}^{-1}$ for a value of $\left.-0.39 \mathrm{~m} \mathrm{a}^{-1}\right)$. This short time interval will hence not be considered, in favour of the longer time interval 1995-2013 over which uncertainties are reduced to yield an acceptable signal to noise ratio of at least 10 .

Like for the AL area change, the results undoubtedly indicate that AL reduced in volume over 1962-2013 with a rate of $-2.5 \pm 0.3 \times 10^{6} \mathrm{~m}^{3} \mathrm{a}^{-1}$ of ice for an average elevation difference of $-0.490 \pm 0.069 \mathrm{~m} \mathrm{a}^{-1}$ (Table 2).

Using the 2009 glacier volume $\left(349 \pm 41 \times 10^{6} \mathrm{~m}^{3}\right)$ obtained by Saintenoy et al. (2013), we can estimate the glacier volume in 1962 by adding ice loss between 1962 and $2009(122 \pm 33 \times$ $10^{6} \mathrm{~m}^{3}$ ): the glacier volume was $471 \pm 74 \times 10^{6} \mathrm{~m}^{3}$ in 1962 . Regarding the 1962-2013 ice loss $\left(129.1 \pm 18.1 \times 10^{6} \mathrm{~m}^{3}\right)$, it therefore represents a high proportion $(27.4 \pm 3.8 \%)$ of the 1962 glacier volume. AL lost $-0.54 \pm 0.07 \%$ per year of its volume over $1962-2013$. 


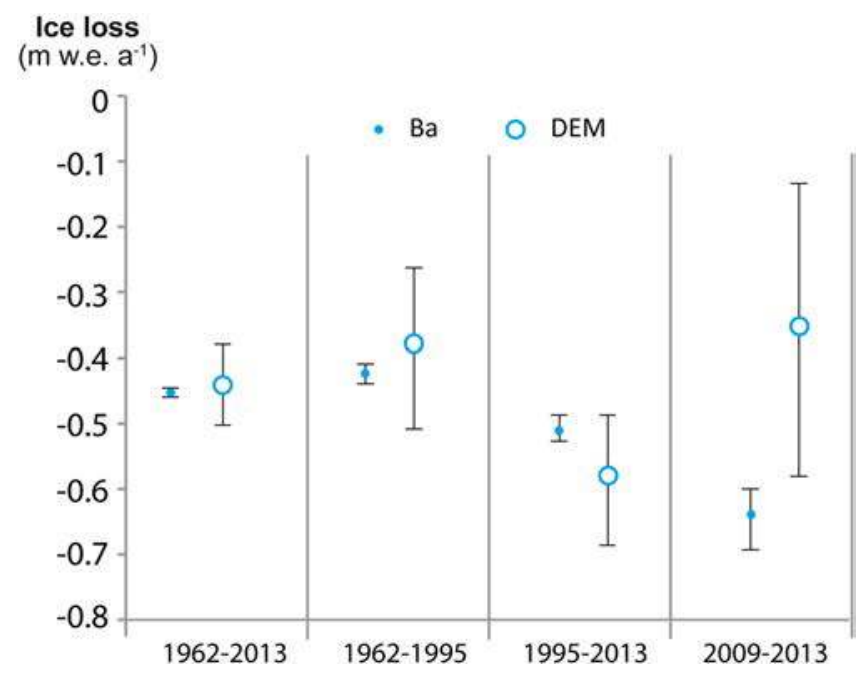

Figure 10. Comparison of methods for estimating AL volume change (Ba and DEM subtraction) for four periods (1962-2013, 19621995, 1995-2013 and 2009-2013).

However, the loss rate was not constant through time and displayed a noticeable acceleration of $30 \%$ between $1962-1995$ and $1995-2013\left(-0.384 \pm 0.123 \mathrm{~m}\right.$ w.e. $\mathrm{a}^{-1}$ for $1962-1995$ versus -0.584 $\pm 0.100 \mathrm{~m}$ w.e. $\mathrm{a}^{-1}$ for 1995-2013; Figures 7 and 10; Table 2). However, the acceleration is better demonstrated with $\mathrm{Ba}$ data because the error bars are lower than the ones on DEM differences. This acceleration is much lower than that given by Kohler et al. (2007) for ML $(+245 \%$ between 1962-1969 and 2003-2005), which was computed on short time-spans instead of continuous, long time series to characterize the changes (1936-2005).

Expressed as change with respect to the whole glacier volume, the glacier lost $16 \pm 5 \%$ of its 1962 volume at an average loss rate of $-0.48 \pm 0.15 \% \mathrm{a}^{-1}$ during the first 33-year period while the glacier lost $14 \pm 2 \%$ of its 1995 volume at a rate of $-0.76 \pm 0.13 \% \mathrm{a}^{-1}$ during the following 18 -year period.

However, the acceleration of the melt rate, perceptible in 1995 since we have a DEM at this date, has to be compared with $B$ a that is measured each year: this issue will be tackled in the next section.

\subsection{AL volume change: DEM subtraction versus $\mathrm{Ba}$ (1962-2013)}

Firstly, regarding the only available past dataset of stake measurements on AL, we can deduce that the ablation rate, obtained by Brossard and Joly (1986) on the partial Geoffray's stake network for $1965-1975$, is of the same order of magnitude $\left(-1.05\right.$ to $-0.24 \mathrm{~m} \mathrm{a}^{-1}$; Table 4$)$ as the loss deduced by DEM differences for the $1962-1995$ period $\left(-1.09\right.$ to $-0.17 \mathrm{~m} \mathrm{a}^{-1}$; Table 4$)$. The mean annual 2008-2013 ablation rate (obtained at the position of Geoffray's stakes) is 1.8 times more negative than the mean rate calculated with the data given by Brossard and Joly (1986) for the 1965-1975 period.

Since stake values of 1965-1975 are not usable for computing an AL Ba, (the retrieved stakes being only located in the ablation area), we used $B$ a reconstructed from long time series of ML $B$ a for 1968-2007 and AB Ba for 1963-1967 in addition to the eight years of in-situ measurements (2008-2015), in order to compare them to DEM differences (see the Sections 3.3 and 4.5).

Results showed that for the overall period (1962-2013), the average altitude difference between DEMs $\left(-0.441 \pm 0.062 \mathrm{~m}\right.$ w.e. $\left.\mathrm{a}^{-1}\right)$ was similar to the average $B \mathrm{a}\left(-0.451 \pm 0.007 \mathrm{~m}\right.$ w.e. $\left.\mathrm{a}^{-1}\right)$, indicating a good consistency between both methods to survey the glacier geometry change (Table 2 ). At shorter time scale, both methods also display similar rates except for the shortest period, 2009-2013 (Figure 10 and Table 2): over 1962-1995, the average $B \mathrm{a}\left(-0.422 \pm 0.016 \mathrm{~m}\right.$ w.e. $\left.\mathrm{a}^{-1}\right)$ is statistically 
similar to DEM subtraction values $\left(-0.384 \pm 0.123 \mathrm{~m}_{\text {w.e. }} \mathrm{a}^{-1}\right)$ and for $1995-2013$, the average Ba $\left(-0.505 \pm 0.020 \mathrm{~m}\right.$ w.e. $\left.\mathrm{a}^{-1}\right)$ is also consistent with DEM subtraction values $(-0.584 \pm 0.100 \mathrm{~m}$ w.e. $\mathrm{a}^{-1}$ ). As already mentioned for DEM differencing (Section 5.2), the increase in the loss rate in time is more highlighted by $\mathrm{Ba}$ data due to low error bars (Figure 10).

As no breakpoint was found in the whole time series of AL Ba (computed from our stake measurements or reconstructed from $\mathrm{ML}$ or $\mathrm{AB} \mathrm{Ba}$ ), the increase of loss rate is likely progressive through time.

All of this confirms that long-term data give accurate and similar results using $B a$ and DEM at the exception of short-term data that yield high error bars. The data presented in this paper reinforce the results obtained for AL by Friedt et al. (2012) by using a more homogenous dataset (Ba compared to DEM difference over similar time intervals) and longer observed Ba time series on AL. Indeed, Friedt et al. (2012) used a different dataset for AL: (i) a 2006 DEM that we discarded in this current investigation due to some poorly covered areas, (ii) they compared $B$ a and DEMs for different years (2008 -2010 for Ba versus 2006-2009 for the DEMs) and (iii) over a shorter period than considered here. Similarly, on ML, Rees and Arnold (2007) also accounted for a discrepancy between 2-DEM differencing and $B$ a computed from stake measurements but they could not relate the 2003-2005 LIDAR data to the $B \mathrm{a}$ of the same period as the latter were not available. Therefore, they compared the 2003 -2005 DEM with mean 1977-1995 Ba values.

\subsection{AL volume change (1962-2013) with respect to catchment area}

To compare the ice volume loss between different periods during which the glacier area reduced, the glacier geometry change has to be given with respect to an area common and invariant over time. We expressed the volume change in water depth (w.e. in $\mathrm{m}$ ) with respect to the catchment area which is considered unchanging in a glacier basin: in the case of AL, the outer edge was chosen where it crosses a stable, massive calcareous outcrop a few hundred metres upstream from the coastline (Figure 1) and which is not affected by changes in coastline position.

The AL ice loss obtained for the whole period by DEM subtraction (Table 2) was $-0.215 \pm$ $0.030 \mathrm{~m}$ w.e. $\mathrm{a}^{-1}$ with respect to the catchment area $\left(10.577 \mathrm{~km}^{2}\right)$. For the same period (1962-2013), the average $B \mathrm{a}$ is $-0.221 \pm 0.003 \mathrm{~m}$ w.e. $\mathrm{a}^{-1}$ with respect to the catchment area, again emphasizing the consistency between the two methods.

Regarding the two periods mentioned above (1962-1995 and 1995-2013), the loss rates, normalized to the catchment area, are still consistent within each period (Table 2; Figures 7 and 10):

- $-0.212 \pm 0.008 \mathrm{~m}$ w.e. $\mathrm{a}^{-1}$ (mean Ba for $\left.1963-1995\right)$ versus $-0.193 \pm 0.062 \mathrm{~m}$ w.e. $\mathrm{a}^{-1}$ (mean annual 1962-1995 DEM subtraction),

- $-0.222 \pm 0.009 \mathrm{~m}$ w.e. $\mathrm{a}^{-1}$ (mean Ba for 1996-2013) versus $-0.256 \pm 0.044 \mathrm{~m}$ w.e. $\mathrm{a}^{-1}$ (mean annual 1995-2013 DEM differences).

Regarding the evolution of loss rates through time, both methods confirm an increase in the loss for the second period (Figure 7). Both proxies indicate increase of the melt rate in the second time interval even if the normalization to catchment area smooths the differences between the two considered periods.

\subsection{AL change with respect to glacier surface exposed to melting (1948-2013)}

From 1962 to 2013, the AL regularly lost ice (-26\% in volume and $-23 \%$ in area). Under similar climatic conditions, we would expect that decreasing the glacier area would lead to a progressive decrease of melt rate, which is not the case for AL for which even though the area decreased, the rate of ice melt (in volume) increased. It is well known that the relationship between glacier size 
and change in ice volume is not straightforward, since a glacier response time must be considered: immediate for volume and delayed for length and area (Cuffey \& Paterson 2010).

To discuss the apparent discrepancy between the overall area change and volume change, we may assess the glacier surface exposed to melting for 1948-2013 using AT data. For this purpose, we chose to compute the area of glacier surface exposed to melting by considering an average elevation of the $0^{\circ} \mathrm{C}$ isotherm based on the MSAT, that is, from May 1 to September 30. This particular time interval was selected as it covers most of the melting period. However, the choice of a constant period allows for the computing of an average $0^{\circ} \mathrm{C}$ isotherm elevation for each date, which has to be considered as relative values rather than absolute values.

For the estimate of the $0^{\circ} \mathrm{C}$ isotherm position, two climatic stations were used: Ny-Ålesund station (1969-2013) and Longyearbyen (1948-1968). As no longitudinal gradient of AT exists between the lower part of the AL catchment and Ny-Ålesund station, the Ny-Ålesund MSAT time series corrected for altitude-AT gradient of $-0.005^{\circ} \mathrm{C} \mathrm{m}^{-1}$ was directly used to estimate yearly the elevation of the $0^{\circ} \mathrm{C}$ isotherm over the glacier from 1969 to 2013 . To extend the time period before 1969 , the Longyearbyen MSAT series was used since (i) this station started earlier than that of Ny-Ålesund and (ii) both monthly AT series (limited to May-September) are very well correlated. We established the relationship at $T(\mathrm{Ny}$-Ålesund $)=0.82 \times T$ (Longyearbyen $)-0.13$ where $T$ is the MSAT in ${ }^{\circ} \mathrm{C}(r=0.95$ and $n=175$ months). These MSAT values was translated into values at AL and corrected for an altitude-AT gradient, then the yearly average elevation of the $0^{\circ} \mathrm{C}$ isotherm for May-September over AL was assessed for 1948-2013. Then, for seven dates for which the AL front position data are available, the area below the $0^{\circ} \mathrm{C}$ isotherm elevation, that is, the area with average positive MSAT was deduced to define a so-called 'glacier area exposed to melting' and reported in Figure 11.

From 1948 to 2013 , we observe an upward shift in elevation of the $0^{\circ} \mathrm{C}$ isotherm, regularly from 1948 (209 $\mathrm{m}$ a.s.l.) to 2013 (454 $\mathrm{m}$ a.s.l.), except for $1962-1977\left(0^{\circ} \mathrm{C}\right.$ isotherm slightly decreased from 276 to $267 \mathrm{~m}$ a.s.l.). At the same time, the glacier area decreased (Figure 11). The AL area exposed to melting substantially increased from $1.9 \mathrm{~km}^{2}$ in 1948 to $3.5 \mathrm{~km}^{2}$ in 2013 , that is, respectively, $30 \%$ and $78 \%$ of the whole area. In 65 years, the glacier area exposed to melting was multiplied by 1.8 while the total AL area reduced by almost a third (29\%). This could be the main explanation of the fact that the change of AL volume increased while its area change decreased.

The evolution of $\mathrm{AL}$ areas, over and under the $0^{\circ} \mathrm{C}$ isotherm elevation, through time is shown in Figure 12. The total glacier area reduced while the area over the $0^{\circ} \mathrm{C}$ isotherm elevation decreased and the area below the $0^{\circ} \mathrm{C}$ isotherm line displayed a noticeable decreasing trend for 1948-1995 and then a strong increase between 1995 and 2013. The breakpoint in 1995 occurs due to the increase in MSAT observed at Ny-Ålesund at this time (cf. Section 4.1).

With such a change in the $0^{\circ} \mathrm{C}$ isotherm position towards higher elevation over the catchment, the average position of the $0^{\circ} \mathrm{C}$ isotherm will soon exceed the upper part of the glacier $(550 \mathrm{~m}$ a.s.l.) during the May-September period and AAR will tend to zero at the end of the summer.

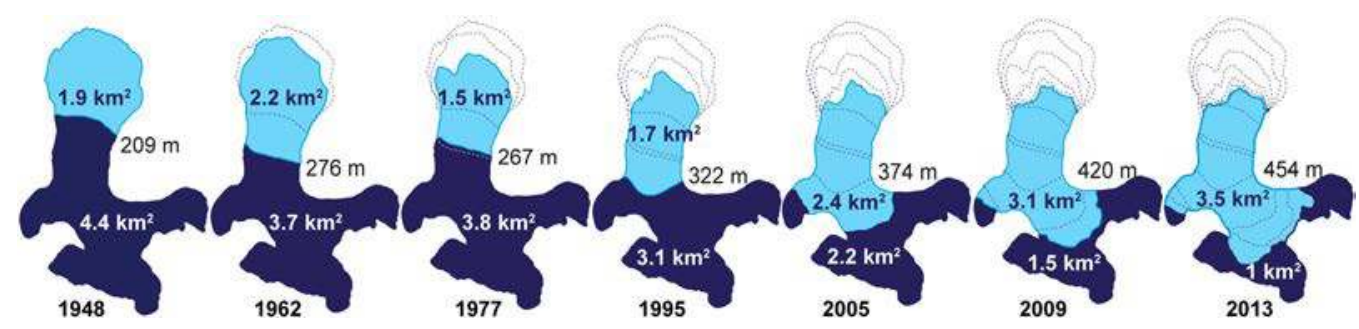

Figure 11. Elevation of the average $0^{\circ} \mathrm{C}$ isotherm over $\mathrm{AL}$ for seven years $(1948,1962,1977,1995,2005,2009$ and 2013). The position of the $0^{\circ} \mathrm{C}$ isotherm elevation was estimated from the Ny-Ålesund temperature data of summer months (May-September) corrected from an elevation gradient of $-0.005^{\circ} \mathrm{C} \mathrm{m}^{-1}$. The values in $\mathrm{km}^{2}$ refer to the glacier area under (light) or over (dark) the $0^{\circ} \mathrm{C}$ isotherm. The values in $\mathrm{m}$ are the elevation of the $0^{\circ} \mathrm{C}$ isotherm. Glacier elevation for 1948 and 1977 is that of 1962 and for 2005 it is that of 2009. 


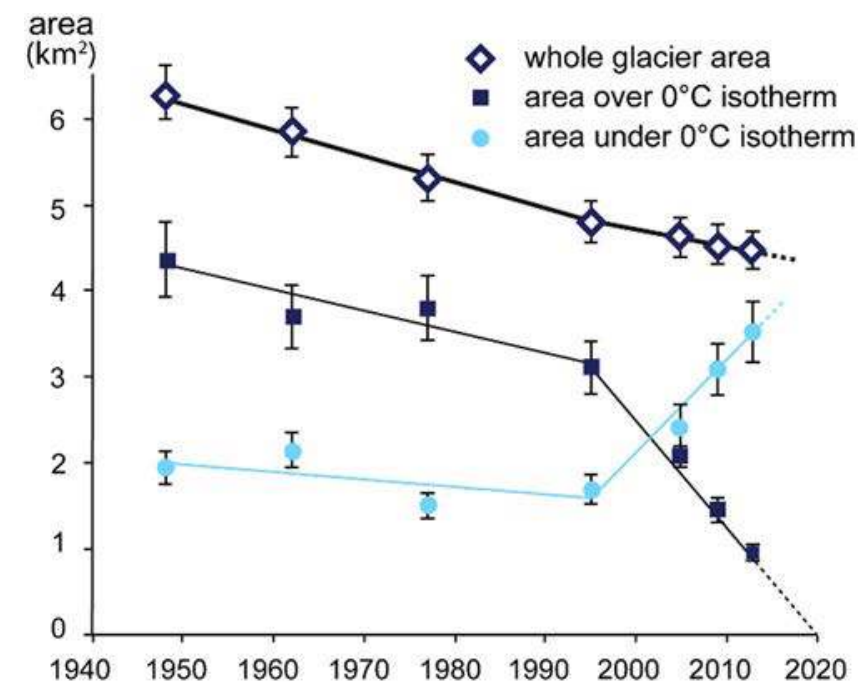

Figure 12. Areas (total, over and under $0^{\circ} \mathrm{C}$ isotherm) as a function of time (1948-2013).

Under such conditions, the glacier area will shrink and the output meltwater volume is then expected to decrease. This geometrical statement might be compensated for by climatic considerations. The melting period could extend in time, before May and/or after September, and MSAT may increase, countering once again the expected decreasing trend that should be seen in the melt rate. The whole glacier surface could be subject to only positive temperatures in the summer by $\sim 2020$ (see regression line of area over $0^{\circ} \mathrm{C}$ extended to $0 \mathrm{~km}^{2}$ in Figure 12). Such conditions might already be met: AAR data between 2008 and 2015 often showed values at or closed to 0\%, in 2011, 2013 and 2015 (Table 3).

\section{Conclusion}

The changes in Austre Lovénbreen geometry were investigated using a set of data and documents whose source was heterogeneous in nature and scale (topographic map, aerial photos, satellite and airborne images). Recent annual mass balance measurements were also used based on a 36stake network established on the Austre Lovénbreen in 2007.

1. Austre Lovénbreen, like neighbouring glaciers of the Brøgger peninsula (e.g. ML), is shrinking. Its total retreat is $1064 \pm 20 \mathrm{~m}$ in length (over seven profiles) over $1948-2013,1.82 \pm 0.28 \mathrm{~km}^{2}$ in area over the same period. The loss in volume is $-129.1 \pm 18.1 \times 10^{6} \mathrm{~m}^{3}$ over $1962-2013$. In half a century, the glacier lost almost a third of its volume, from $471 \pm 74 \times 10^{6}$ in 1962 to 342 $\pm 46 \times 10^{6} \mathrm{~m}^{3}$ in 2013 .

2. Austre Lovénbreen average annual rates were the following: $-16.7 \pm 0.3 \mathrm{~m} \mathrm{a}^{-1}$ in length for $1948-2013,-0.027 \pm 0.002 \mathrm{~km}^{2} \mathrm{a}^{-1}$ in area for $1948-2013$ and $-2.3 \pm 0.3 \times 10^{6} \mathrm{~m}^{3}$ w.e. $\mathrm{a}^{-1}$ for $1962-2013$, that is, $-0.54 \pm 0.07 \% \mathrm{a}^{-1}$ of the 1962 glacier volume.

3. The mean annual mass balance over 1962-2013 (-0.221 $\pm 0.003 \mathrm{~m}$ w.e. with respect to the Austre Lovénbreen catchment area) is comparable to the DEM subtraction values $(-0.215 \pm 0.030 \mathrm{~m}$ w.e. with respect to the catchment area). The good agreement between the two methods used to survey the annual glacier volume change demonstrates that the DEM difference is an efficient method if applied at dates separated by a time interval long enough for the altitude uncertainty to become negligible with respect to mass balance: in our case, such a condition is met for durations reaching a decade. 
4. The perceptible breakpoint between 1990 and 1995 (decrease of area change rate from $-0.032 \pm$ $0.003 \mathrm{~km}^{2} \mathrm{a}^{-1}$ for $1948-1995$ to $-0.018 \pm 0.005 \mathrm{~km}^{2} \mathrm{a}^{-1}$ for $1995-2013$ ) is explained by the increased local influence of the topography of the surrounding terrain, inducing a thicker and less wide glacier terminus.

5. Regarding two periods (1962-1995 and 1995-2013), the increase in the loss rate in time is more highlighted by $B$ a data than DEM subtraction, due to low error bars: over 1962-1995, the average $B$ a was $-0.422 \pm 0.016 \mathrm{~m}$ w.e. $\mathrm{a}^{-1}$ whereas it was $-0.505 \pm 0.020 \mathrm{~m}$ w.e. $\mathrm{a}^{-1}$ or $1995-2013$ ). Assuming the relative volume loss remains similar to that estimated from DEM difference for $1995-2013\left(-0.76 \pm 0.13 \% \mathrm{a}^{-1}\right)$, the glacier would have completely melted in $132 \pm 27$ years.

6. Between the periods used to study the glacier volume change (1962-1995 and 1995-2013), Austre Lovénbreen reduced its volume by $26 \%$ while its area dropped by $23 \%$. AL area exposed to melting was modelled by assessing the $0^{\circ} \mathrm{C}$ isotherm elevation over the glacier by averaging May-September AT (from Ny-Ålesund station and extended to 1948 using the Longyearbyen AT) from 1948 to 2013 and applying an AT - altitude gradient of $-0.005^{\circ} \mathrm{C} \mathrm{m}^{-1}$. The $0^{\circ} \mathrm{C}$ isotherm elevation rose over the glacier by $250 \mathrm{~m}$ on average in 65 years. The glacier area exposed to melting during the May-September period almost increased by 1.8 -fold while the total Austre Lovénbreen area reduced by almost a third since 1948 (29\%).

Austre Lovénbreen already experienced negative mass balance over the entire glacier surface (for instance in 2011 and 2013 when AAR was at or closed to $0 \%$ ). In 2013, only $1.0 \mathrm{~km}^{2}$ of the total glacier area $\left(4.48 \mathrm{~km}^{2}\right)$ was over the $0^{\circ} \mathrm{C}$ isotherm. If this continues, within a few years, the glacier area exposed to melting will reduce as the entire present-day accumulation area will be under the $0^{\circ} \mathrm{C}$ isotherm while the snout will keep on retreating. This would then eventually imply a reduction of ice melt if ATs remain at least similar.

\section{Acknowledgements}

The authors wish to acknowledge the French-German AWIPEV Arctic collaborative base for having provided logistic support in the field. G. Rees and J. Kohler, who kindly provided useful data needed for this work, are warmly thanked for their contribution. Anonymous reviewers are thanked for critically reading the manuscript and suggesting substantial improvements.

\section{Disclosure statement}

No potential conflict of interest was reported by the authors.

\section{Funding}

The project was funded by the French Agence Nationale de la Recherche (ANR ) (programme blanc, the projects Hydro-Sensor-FLOWS and Cryo-Sensors) and by the Institut polaire français Paul-Emile Victor (IPEV, programme 304), Groupement de Recherche CNRS 'Mutations Polaires'.

\section{Notes on contributors}

Christelle Marlin is at Laboratoire Geosciences Paris-Sud, GEOPS, UMR 8148, Université Paris-Sud, Orsay Cedex, France.

Florian Tolle is at Laboratoire ThéMA, UMR 6049, Université de Bourgogne Franche-Comté - CNRS, Besançon, France.

Madeleine Griselin is at Laboratoire ThéMA, UMR 6049, Université de Bourgogne Franche-Comté - CNRS, Besançon, France.

Eric Bernard is at Laboratoire ThéMA, UMR 6049, Université de Bourgogne Franche-Comté - CNRS, Besançon, France. 
Albane Saintenoy is at Laboratoire Geosciences Paris-Sud, GEOPS, UMR 8148, Université Paris-Sud 11 - CNRS, Université Paris-Sud, Orsay Cedex, France.

Mélanie Quenet is at Laboratoire Geosciences Paris-Sud, GEOPS, UMR 8148, Université Paris-Sud 11 - CNRS, Université Paris-Sud, Orsay Cedex, France.

Jean-Michel Friedt is at Laboratoire FEMTO-ST, UMR 6174, Université de Bourgogne Franche-Comté - CNRS, Besançon, France.

\section{References}

Barrand NE, James TD, Murray T. 2010. Spatio-temporal variability in elevation changes of two high-arctic valley glaciers. J Glaciol. 56. 771-780.

Bernard E. 2011. Les dynamiques spatio-temporelles d'un petit hydro-système arctique: approche nivo-glaciologique dans un contexte de changement climatique contemporain (bassin du glacier Austre Lovén, Spitsberg, $79^{\circ} \mathrm{N}$ ) $[\mathrm{PhD}$ thesis]. Besançon: Université de Franche-Comté; p. 400.

Bernard E, Friedt J-M, Saintenoy A, Tolle F, Griselin M, Marlin C. 2014. Where does a glacier end? GPR measurements to identify the limits between valley slopes and actual glacier body. Application to the Austre Lovénbreen, Spitsbergen. Int J Appl Earth Obs Geoinf. 27:100-108.

Bernard E, Friedt J-M, Tolle F, Griselin M, Martin G, Laffly D, Marlin C. 2013. Monitoring seasonal snow dynamics using ground based high resolution photography (Austre Lovénbreen, Svalbard, $79^{\circ} \mathrm{N}$ ). J Photogramm Remote Sens. 75:92-100.

Bernard E, Tolle F, Griselin M, Laffly D, Marlin C. 2010. Quantification des hauteurs de neige et des températures de l'air à la surface d'un glacier: du terrain à l'interpolation, confrontation de méthodes. In: Foltête JC, Dir. Actes des Neuvièmes Rencontres de Théo Quant. Besançon, 4-6 mars.

Brandt O, Kohler J. 2006. A long-term Arctic snow depth record from Abisko, northern Sweden, 1913-2004. Polar Res. 25:91-113.

Brossard T, Joly D. 1986. Le complexe géomorphologique aval des glaciers Lovén Est et Central (Svalbard). Cah Géogr Besançon (Nlle sér). 2:5-58.

Cogley JG, Hock R, Rasmussen LA, Arendt AA, Bauder A, Braithwaite RJ, Jansson P, Kaser G, Möller M, Nicholson L, Zemp M. 2011. Glossary of glacier mass balance and related terms, IHP-VII Technical Documents in Hydrology, 86, IACS Contribution No. 2.UNESCO-IHP, Paris.

Corbel J. 1966. Spitsberg 1964 et premières observations 1965. CNRS-RCP 42, éd. Audin; p. 350.

Corbel J. 1970. Le Spitsberg. Présentation géographique - mission française 1966. Mém Doc Cent Doc Cartogr Géogr CNRS. 10:23-35.

Cufffey K, Paterson W. 2010. The physics of glaciers. Burlington (MA): Elsevier. ISBN 978-0-12-369461-4, p. 704.

Dyurgerov M, Bring A, Destouni G. 2010. Integrated assessment of changes in freshwater inflow to the Arctic Ocean. J Geophys Res. 115. doi:10.1029/2009JD013060.

Dyurgerov M, Meier MF, Bahr DB. 2009. A new index of glacier area change; a tool for glacier monitoring. J Glaciol. 55:710-716.

eKlima. 2013. See the database on the web portal which gives free access to the climate database of the Norwegian Meteorological Institute. Available from: http://eklima.met.no

Fontain AG, Vecchia A. 1999. How many stakes are required to measure the mass balance of a glacier? Geogr Ann. 81 A:563-573.

Førland EJ, Benestad R, Hanssen-Bauer I, Haugen JE, Skaugen TE. 2011. Temperature and precipitation development at Svalbard 1900-2100. Adv Meteorol. doi:10.1155/2011/893790.

Friedt JM, Tolle F, Bernard E, Griselin M, Laffly D, Marlin C. 2012. Assessing the relevance of digital elevation models to evaluate glacier mass balance: application to Austre Lovénbreen (Spitsbergen, 79º N). Polar Rec. 48:2-10.

Geoffray H. 1968. Étude du bilan hydrologique et de l'érosion sur un bassin partiellement englacé : Spitsberg, baie du Roi, $79^{\circ} \mathrm{N}$ [PhD thesis]. Brest: Université de Brest; p. 103.

Gregory JM, White NJ, Church JA, Bierkens MFP, Box JE, van den Broeke MR, Cogley JG, Fettweis X, Hanna E, Huybrechts P, et al. 2013. Twentieth-century global-mean sea level rise: is the whole greater than the sum of the Parts? J Clim. 26:4476-4499.

Griselin M. 1982. Les écoulements solides et liquides sur les marges polaires, exemple du bassin de Lovén Est, $79^{\circ} \mathrm{N}$, Spitsberg [PhD thesis]. Nancy: Université de Nancy-2; p. 500.

Griselin M. 1985. L'abondance annuelle et le bilan hydrologique d'un bassin partiellement englacé de la côte nordouest du Spitsberg. Norois. 32:19-33.

Griselin M, Marlin C. 1999. Approche quantitative et géochimique du gradient altitudinal des précipitations sur un bassin versant partiellement englacé de la côte occidentale du Spitsberg. Houille Blanche. 5:125-136.

Haakensen N. 1986. Glacier mapping to confirm results from mass-balance measurements. Ann Glaciol. 8:73-75.

Hagen JO, Liestøl O. 1990. Long-term glacier mass-balance investigations in Svalbard. Ann Glaciol. 14:102-106. 
Hagen JO, Liestøl O, Roland E, Jorgensen T. 1993. Glacier atlas of Svalbard and Jan Mayen. Norsk Polarintitutt Meddelelser, 129; p. 160.

Hagen JO, Melvold K, Pinglot F, Dowdeswel JA. 2003. On the net mass balance of the glaciers and ice caps in Svalbard, Norwegian Arctic. Arct Antarct Alp Res. 35:264-270.

Hansen S. 1999. A photogrammetry, climate-statistical and geomorphological approach to the post Little Ice Age changes of the Midtre Lovénbreen glacier, Svalbard [Master thesis]. University of Tromsø and University of Copenhage; p. 92.

Hock R. 2005. Glacier melt: a review of processes and their modelling. Prog Phys Geogr. 29:362-391.

James TD, Murray T, Barrand NE, Sykes HJ, Fox AJ, King MA. 2012. Observations of enhanced thinning in the upper reaches of Svalbard glaciers. Cryosphere. 6:1369-1381.

Joly D. 1994. Ambiances climatiques instantanées au Spitsberg; pour une approche méthodique par niveau d'échelle. Annales Littéraires de l’Université de Franche-Comté, Besançon. n529, Diffusion Les Belles Lettres.

Kohler J, James TD, Murray T, Nuth C, Brandt O, Barrand NE, Aas HF, Luckman A. 2007. Accelerating in thinning rate on western Svalbard glaciers. Geophys Res Lett. 24. doi:1029/2007GL030681.

Korona J, Berthier E, Bernard M, Remy F, Thouvenot E. 2009. SPIRIT. SPOT 5 stereoscopic survey of polar ice: reference images and topographies during the fourth International Polar Year (2007-2009). J Photogramm Remote Sens. 64:204-212.

Lefauconnier B, Hagen J-O. 1990. Glaciers and climate in Svalbard, statistical analysis and reconstruction of the Brøgger glacier mass balance for the last 77 years. Ann Glaciol. 14:148-152.

Lefauconnier B, Hagen J-O, Ørbæk JB, Melvold K, Isaksson E. 1999. Glacier balance trends in the Kongsfjord area, western Spitsbergen, Svalbard, in relation to the climate. Polar Res. 18:307-313.

Liestøl O. 1993. Glacier of Svalbard, Norway. US Geological Survey Professional Paper 1386-E-5.

Meier MF, Dyurgerov MB, Rick UK, O’Neel S, Pfeffer WT, Anderson RS, Anderson SP, Glazovsky AF. 2007. Glaciers dominate eustatic sea-level rise in the 21st century. Science. 317:1064-1067.

Mingxing X, Ming Y, Jiawen R, Songtao A, Jiancheng K, Dongchen E. 2010. Surface mass balance and ice flow of the glaciers Austre Lovénbreen and Pedersenbreen, Svalbard, Arctic. Chin J Polar Sci. 21:147-159.

Moholdt G, Nuth C, Hagen JO, Kohler J. 2010. Recent elevation changes of Svalbard glaciers derived from ICESat laser altimetry. Remote Sens Environ. 114:2756-2767.

Murray T, Booth A, Rippin D. 2007. Limitations of glacier ice-water content estimated using velocity analysis of surface ground-penetrating radar surveys. J Environ Eng Geophys. 12:87-99.

Oosterbaan RJ. 1994. Frequency and regression analysis of hydrologic data. Chapter 6. In: Ritzema HP, editor. Drainage principles and applications, Publication 16. Second revised edition. Wageningen: International Institute for Land Reclamation and Improvement (ILRI); p. 175-223.

Østrem G, Brugman M. 1991. Glacier mass-balance measurements: a manual for field and office work. National Hydrology Research Institute - NHRI Science Report, No. 4; p. 220.

Paterson WSB. 1994. The physics of glaciers. 3rd ed. Oxford: Pergamon; p. 480.

Pillewizer W. 1967. Zur Karte des Kongsvegen-Kronebre 1/50,000, Estspitzbergen. Petermanns Geogr Mitleilungen, Jahrg. Ill, Quartalsht. 2:153-157.

Radić V, Bliss A, Beedlow AC, Hock R, Miles E, Cogley JG. 2013. Regional and global projections of twenty-first century glacier mass changes in response to climate scenarios from global climate models. Clim Dyn. 42:37-58.

Rees WG, Arnold NS. 2007. Mass balance and dynamics of a valley glacier measured by high-resolution LiDAR. Polar Rec. 43:311-319.

Rignot E, Kanagaratnam P. 2006. Changes in the velocity structure of the Greenland Ice Sheet. Science. 311:986-990.

Rippin D, Willis I, Arnold N, Hodson A, Moore J, Kohler J, Bjornsson H. 2003. Changes in geometry and subglacial drainage of Midre Lovénbreen, Svalbard, determined from digital elevation models. Earth Surf Process Landf. 28:273-298.

Saintenoy A, Friedt J-M, Booth AD, Tolle F, Bernard E, Laffly D, Marlin C, Griselin M. 2013. Deriving ice thickness, glacier volume and bedrock morphology of Austre Lovénbreen (Svalbard) using GPR. Near Surf Geophys. 11:253-261.

Stocker TF, Qin D, Plattner G-K, Tignor M, Allen SK, Boschung J, Nauels A, Xia Y, Bex V, Midgley PM. 2013. IPCC: Climate change 2013: the physical science basis. In: Contribution of Working Group I to the Fifth Assessment Report of the Intergovernmental Panel on Climate Change, editor. Cambridge: Cambridge University Press; p. 1535. doi:10.1017/CBO978110741532.

Vincent C, Vallon M, Reynaud L, and Le Meur E. 2000. Dynamic behaviour analysis of glacier de St Sorlin, France from 40 years of observations, 1957-1997. J Glaciol. 46:499-506.

Vincent M, Geoffray H. 1970. Etude d'un régime glaciaire en fonction de la température et de l'ensoleillement, Baie du Roi, (été 1966). Mém Doc CNRS. 10:219-229.

Vivian H. 1964. Premières observations sur le régime estival des torrents glaciaires du Spitsberg (79 latitude Nord). Norois. 43:283-307.

WGMS. 2016. World glacier monitoring service under the hospice of ICSU, IUGG, UNEP, UNESCO, WMO. Available from: http://www.wgms.ch 